\title{
The Constitutional Experience of Lithuania in the Context of European and Global Governance Challenges
}

\author{
Irmantas Jarukaitis and Gintaras Švedas
}

\begin{abstract}
The Lithuanian Constitution (1992) is described in the report as a typical revolutionary constitution, adopted after the collapse of a totalitarian regime. The Constitutional Court (CC) is a strong player both in terms of the protection of fundamental rights and as an arbitrator in political disputes. The report observes that due to their bitter historical struggle for statehood, Lithuanians have generally treated membership in the EU as a fundamental geopolitical choice. From this perspective, the Constitution is unique, as it was - in a self-standing constitutional act - extensively opened to the EU, whilst another constitutional act prohibits joining any union based on the former USSR. The CC has held that the Constitution establishes a constitutional imperative of EU and NATO membership. By and large, no critical constitutional debates have arisen in relation to EU and transnational law. Some exceptions include an (unsuccessful) request to hold a referendum on the adoption of the euro on the ground that the nature of the EMU had been changed by the ESM Treaty due to the extensive financial liabilities it might entail. The report notes that these discussions were overshadowed by events in Ukraine and geopolitical security concerns. The report also observes a lack of real discussion both in academia and in the public discourse concerning various issues decided at the EU
\end{abstract}

Irmantas Jarukaitis is Judge at the Court of Justice of the Europen Union; at the time of writing, Vice-President, Supreme Administrative Court of Lithuania, and Associate Professor at the Faculty of Law, University of Vilnius. e-mail: Irmantas.Jarukaitis@ curia.europa.eu.

Gintaras Švedas is Professor and Vice-Dean of the Faculty of Law, University of Vilnius. e-mail: gintaras.svedas@tf.vu.lt.

Irmantas Jarukaitis wrote Sects. 1.1.1-2.2.1 and 2.4.1-3.5.2. Gintaras Švedas wrote Sects. 2.3.1.1-2.3.6.

All websites accessed 12 November 2015. Text submitted 23 April 2015.

I. Jarukaitis $(\bowtie)$

Court of Justice of the European Union, Luxembourg, Luxembourg

e-mail: Irmantas.Jarukaitis@curia.europa.eu

I. Jarukaitis · G. Švedas

University of Vilnius, Vilnius, Lithuania

e-mail: gintaras.svedas@tf.vu.lt

(C) The Author(s) 2019

A. Albi and S. Bardutzky (eds.), National Constitutions in European

and Global Governance: Democracy, Rights, the Rule of Law,

https://doi.org/10.1007/978-94-6265-273-6_21 
level, which later have had a profound impact upon implementation at the national level (e.g. the Data Retention Directive), and calls for stimulating such discussion.

Keywords The Constitution of Lithuania - EU amendments in the Constitution The Lithuanian Constitutional Court • Referendum • European Arrest Warrant and extradition statistics - Data Retention Directive - Adoption of the euro ESM Treaty - Geopolitics and security - Lack of public and scholarly debate on EU issues - Parliamentary reservation of law regarding state loans - The principles of legal certainty, legitimate expectations and sound administration

Social rights and austerity $\cdot$ Property rights $\cdot$ Sugar Stocks cases • NATO

\section{Constitutional Amendments Regarding EU Membership}

\subsection{Constitutional Culture}

1.1.1 The Constitution of the Republic of Lithuania that is currently in force was adopted by way of a referendum on 25 October 1992. It was adopted after the re-establishment of the independence of Lithuania after fifty years of Soviet occupation. With the re-establishment of independence on 11 March 1990, there was an aspiration to emphasise the continuity of the Lithuanian state despite the Soviet occupation. Thus, when the Supreme Council of the Republic of Lithuania adopted the Act on the Re-establishment of the State of Lithuania on 11 March 1990, the next step was the adoption of the Law on the Reinstatement of the Validity of the Last Pre-war Constitution of the Then Independent Republic of Lithuania - the Constitution of 12 May 1938. Still, this was a purely symbolic act, since everybody understood that the political, legal and social environment was totally different than before World War II. Therefore, on the same day, the Supreme Council adopted a law which terminated the validity of the Constitution of 12 May 1938 and approved the Provisional Basic Law, which was applicable until the entry into force of the Constitution of 25 October 1992.

Thus, it might be said that there are certain symbolic elements of evolutionary character in the Constitution, especially given the fact that its Preamble explicitly mentions the Lithuanian Statutes (modern basic laws, adopted in the Middle Ages) and the earlier Constitutions of Lithuania ${ }^{1}$ as sources of inspiration. However, in reality the Constitution of 25 October 1992 is a typical revolutionary constitution,

\footnotetext{
${ }^{1}$ It should be noted that the Lithuanian-Polish Commonwealth stood at the forefront of modern European constitutionalism with the first modern European Constitution - the Constitution of 3 May 1791 of the Lithuanian-Polish Commonwealth, which was amended by the Mutual Pledge of the Two Nations of 20 October 1791. Due to historic circumstances (the Third partition of the Commonwealth), the Constitution was renounced two years later. After the establishment of the independence of Lithuania on 16 February 1918, the Republic experienced a short period with its own constitutional tradition, starting with a temporary constitution adopted in 1918, and ending with the Constitution adopted on 12 May 1938.
} 
adopted after the collapse of a totalitarian regime, similar to the constitutions of other Central and Eastern European states adopted after the fall of the Berlin Wall. It has a rigid, detailed legal character and establishes a constitutional court which plays a central role in ensuring the observance of the Constitution and the protection of constitutional fundamental rights. Furthermore, Art. 6 of the Constitution provides for its direct applicability. ${ }^{2}$ Similarly to the constitutional courts in other Central and Eastern European states, the Constitutional Court of the Republic of Lithuania (CC) is a very strong player both in terms of the protection of fundamental rights and as an arbitrator in disputes between different branches of public (political) power.

The Constitution is also a very important legal tool for performing the judicial functions of the courts of general competence and the administrative courts of Lithuania. These courts are very active in questioning the legality of acts of the Parliament and of the Government and referring cases to the CC. By doing so they contribute to the establishment of a de facto decentralised system of constitutional review, although, of course, de jure and de facto the $\mathrm{CC}$ has the sole responsibility for scrutinising the constitutionality of acts of the Parliament, the President and the Government.

1.1.2 The Constitution performs the traditional functions accorded to it by the classic constitutional doctrine. ${ }^{3}$ First of all, it is treated as a fundamental legal document, establishing the state of Lithuania. Chapter I of the Constitution ('the State of Lithuania') revolves around the notions of people's (national) and state sovereignty, democratic rule, limitation and separation of powers, supremacy of the Constitution and its direct applicability, the official state language (Lithuanian) and the symbols of the state. Chapter II ('The Human Being and the State') establishes the fundamental rights and freedoms of individuals, whereas Chapter III ('Society and the State') and Chapter IV ('National Economy and Labour') are reflections of the communal/societal aspects of the Constitution. The remainder (Chaps. V-XIII) deals primarily with the organisation and functioning of public power.

The jurisprudence of the $\mathrm{CC}$ and academic writings reflect the classic understanding of the Constitution: the Lithuanian people (nation) are the source of the Constitution, which is the supreme law of the land. The Constitution reflects the social contract - an imperative vision, a democratically accepted obligation by all of the citizens of Lithuania for the current and future generations to live according to the fundamental rules entrenched in the Constitution and to obey them in order to ensure the legitimacy of the governing power, the legitimacy of its decisions, as well as to ensure human rights and freedoms, so that harmony exists in society. The CC makes it clear that the Constitution is based on universal, unquestionable values, which are sovereignty belonging to the Nation, democracy, the recognition

\footnotetext{
2 'The Constitution shall be an integral and directly applicable act. Everyone may defend his rights by invoking the Constitution'. The English translation of the Constitution quoted in this report is available on the website of the Seimas at http://www3.lrs.lt/pls/inter3/dokpaieska.showdoc_e?p_ $\mathrm{id}=275302$.

${ }^{3}$ Jarašiūnas 2001, pp. 103-130; Šileikis 2005, pp. 52-71.
} 
of and respect for human rights and freedoms, respect for the law and the rule of law, limitation of the scope of powers, the duty of state institutions to serve the people and their responsibility to society, public spirit, justice, and striving for an open, just and harmonious civil society and state under the rule of law. ${ }^{4}$

To sum up, the Constitution may be treated as a material reflection of the usual dimensions of constitutionalism: ${ }^{5}$ constitutionalism as a limit to public power, constitutionalism as a polity expression and constitutionalism as deliberation or, using the notion proposed by J. Raz, a 'thick' constitution. ${ }^{6}$

As regards the centre of gravity among these dimensions of the Constitution, attention should be drawn to the fact that Art. 1 speaks of Lithuania as an 'independent democratic republic'. Thus, the independence of the state is placed before its democratic nature. Moreover, differently than in some other EU Member States, Chap. I of the Constitution is devoted not to fundamental rights, but to the state as a common good of the Lithuanian people. It seems that this sequence is not accidental given the bitter historic experience of the Lithuanian people and the fact that the Constitution was adopted at the time when the Soviet army was still in the country (the last Russian army troops left Lithuania on 31 August 1993). Given the very sovereignist language of the Constitution, ${ }^{7}$ the jurisprudence of the $\mathrm{CC}$ as well as the political culture and the general mood among the public, it could be said that the Constitution first of all gravitates to the reflection of the continuing statehood of Lithuania, although this does not mean that the other dimensions of the Constitution are less important.

\subsection{The Amendment of the Constitution in Relation to the European Union}

1.2.1 Lithuania's membership in the EU has always been seen as more than participation in an economic union. Given their bitter experience and the struggle for the right to statehood over the last two centuries, Lithuanians have generally treated (and still treat) membership in the EU as a fundamental geopolitical choice between 'the East and the West'. From this perspective the Constitution of Lithuania is unique, since it establishes explicit provisions on both the negative ${ }^{8}$ and the positive

\footnotetext{
${ }^{4}$ Rulings of 25 May 2004; 19 August 2006; 24 September 2009; 24 January 2014; Decisions of 20 April 2010; 19 December 2012. Here and subsequently, the translations quoted are the English translations of the rulings, conclusions and decisions of the $\mathrm{CC}$ available at www.lrkt.lt.

5 For different dimensions of constitutionalism see, for example, Poiares Maduro 2004, Šileikis 2005, pp. 35-71 and Walker 2006.

${ }^{6}$ For the notion of a 'thick' constitution see, in particular Raz 1998, pp. 152-193.

${ }^{7}$ Albi 2001, pp. 437-440, Jarukaitis 2011, pp. 261-266.

${ }^{8}$ The Supreme Council adopted the Constitutional Act on the Non-Alignment of the Republic of Lithuania to Post-Soviet Eastern Unions on 8 June 1992. The Act is a part of Lithuanian positive constitutional law and states, inter alia, that the Supreme Council shall resolve 'To develop mutually advantageous relations with each state which was formerly a component of the USSR,
} 
geopolitical orientation (see further the Constitutional Act on Membership of the Republic of Lithuania in the European Union (hereinafter CA). The first hint of the positive geopolitical orientation was established on 20 June 1996 when Art. 47 of the Constitution was amended in order to ensure its compatibility with the Europe Agreement. $^{9}$

Just one month before the entry into force of the Europe Agreement, the Board of the Parliament decided to form an expert group to evaluate the necessity of any constitutional amendments with regard to the prospective accession of Lithuania to the EU. The expert group concluded that although there was no conceptual/ fundamental obstacle in the Constitution to joining the EU, constitutional amendments were necessary in order to ensure a proper constitutional basis for such membership, and proposed concrete draft amendments. ${ }^{10}$ The Government officially submitted the proposed EU related amendments to the Constitution to the Parliament on 1 March 2001. However, in 2001 the Constitutional Amendments Commission decided that no constitutional amendments were needed, although it acknowledged that it might be necessary to return to the issue at a later date. ${ }^{11}$

The new impetus for renewing public discussions concerning the EU-related constitutional amendments was provided by the establishment of the European Convention and the result of its activities, the Treaty Establishing a Constitution for Europe, which prompted the Parliament to form several new working groups. ${ }^{12}$ Finally, on 2 October 2003, the Constitutional Amendments Commission decided that constitutional amendments establishing a constitutional basis for Lithuania's

but to never join in any form any new political, military, economic or other unions or commonwealths of states formed on the basis of the former USSR' (translation by the author).

${ }^{9}$ The Constitution adopted in 1992 totally precluded the right of foreigners to acquire land in Lithuania. However, once the Europe Agreement was signed in 1995, this prohibition was partially lifted and Art. 47 of the Constitution was supplemented with para. 2: 'Local governments (municipalities), other national entities as well as those foreign entities conducting economic activities in Lithuania which are specified by the constitutional law in compliance with the criteria of European and Transatlantic integration which the Republic of Lithuania has embarked on may be permitted to acquire into their ownership non-agricultural land plots required for the construction and operation of buildings and facilities necessary for their direct activities'.

${ }^{10}$ The text of the constitutional amendments proposed by the expert group may be found in: Stojimas i Europos Sajunga ir Konstitucija. Seminaro medžiaga 199906 29-30 d (Accession to the European Union and the Constitution. Materials of the seminar of 29-30 June 1999). Eugrimas, Vilnius, 2000, pp. 23-25. Basically, the proposed amendments included provisions concerning transfer of part of the competences of state institutions to the EU and the incorporation of EU law into the national legal system. It should also be noted that these draft amendments were discussed during an international seminar which took place in Vilnius in 1999. The comments of Lithuanian and foreign experts may be found in the above-mentioned book. By way of a summary, the majority of participants in the seminar shared the opinion that constitutional amendments were necessary.

11 The Report of activities of the Commission of 2001 at http://www3.1rs.lt/pls/inter/w5_show?p_ $\mathrm{r}=894 \& \mathrm{p} \_\mathrm{d}=14315 \& \mathrm{p} \_\mathrm{k}=1$.

${ }^{12}$ Before the European Convention started, the Seimas decided to establish several working groups of experts, which had the task of formulating various suggestions to the Lithuanian members of the Convention as regards the issues discussed at the Convention. 
membership within the EU were necessary. The Commission decided not to amend the main body of the Constitution but to proceed with a separate constitutional act, and agreed on the content of this constitutional act on 11 December 2003. A group of Members of Parliament formally submitted the draft amendments to the Constitution for deliberation in Parliament on 22 December 2003. Although several technical adjustments were made to the draft during the deliberations in Parliament, the form (a separate constitutional act), the structure (4 separate articles) and the essence of the content of the initial draft were retained. The Parliament followed the usual procedure (see Sect. 1.2.2) established in the Constitution for adoption of constitutional amendments and adopted the Law Supplementing the Constitution with the Constitutional Act on Membership of the Republic of Lithuania in the European Union and Supplementing Art. 150 of the Constitution on 13 July $2004 .^{13}$ The amendments took effect as of 14 August 2004.

\footnotetext{
${ }^{13}$ The Constitutional Act on Membership of the Republic of Lithuania in the European Union provides:
}

The Seimas of the Republic of Lithuania,

executing the will of the citizens of the Republic of Lithuania expressed in the referendum on the membership of the Republic of Lithuania in the European Union, held on 10-11 May 2003;

expressing its conviction that the European Union respects human rights and fundamental freedoms and that the Lithuanian membership in the European Union will contribute to a more efficient securing of human rights and freedoms,

noting that the European Union respects the national identity and constitutional traditions of its Member States, seeking to ensure a fully-fledged participation of the Republic of Lithuania in European integration as well as the security of the Republic of Lithuania and welfare of its citizens, ...

adopts and proclaims this Constitutional Act:

1. The Republic of Lithuania as a Member State of the European Union shall share with or entrust on the European Union the competences of its State institutions in the areas provided for in the founding Treaties of the European Union and to the extent it would, together with the other Member States of the European Union, jointly meet its membership commitments in those areas as well as enjoy membership rights.

2. The norms of European Union law shall be a constituent part of the legal system of the Republic of Lithuania. Where it concerns the founding Treaties of the European Union, the norms of European Union law shall be applied directly, while in the event of a collision of legal norms, they shall have supremacy over the laws and other legal acts of the Republic of Lithuania.

3. The Government shall inform the Seimas of proposals to adopt acts of European Union law. As regards proposals to adopt acts of European Union law regulating areas which, under the Constitution of the Republic of Lithuania, are related to the competences of the Seimas, the Government shall consult the Seimas. The Seimas may recommend a position of the Republic of Lithuania in respect of these proposals to the Government. The Seimas Committee on European Affairs and the Seimas Committee on Foreign Affairs may, according to the procedure established by the Statute of the Seimas, submit to the Government the opinion of the Seimas concerning proposals to adopt acts of the European Union law. The Government shall assess the recommendations or opinions submitted by the Seimas or its Committees and shall inform the Seimas about their execution following the procedure established by legal acts.

4. The Government shall consider proposals to adopt acts of European Union law following the procedure established by legal acts. As regards these proposals, the Government may adopt decisions or resolutions for the adoption of which the provisions of Art. 95 of the Constitution are 
There were discussions in Parliament on whether to adopt the CA by way of a referendum or to leave this to the Parliament. The latter option was chosen, although the adoption of the CA was preceded by a referendum with a question on whether Lithuania should accede to the EU.

Given the fact that the adoption of the CA de facto meant a revision of the entire Constitution (see Sect. 1.3.1), including its Chapter I (which may only be amended by way of a referendum (see Sect. 1.2.2)), one may wonder whether it would have been more appropriate to submit the adoption of the CA to a referendum.

It may be interesting to note that the $\mathrm{CA}$ was adopted and took effect after Lithuania's accession to the EU. The reasons for this delay are not clear, as both Lithuanian society in general and the political parties represented in Parliament widely supported Lithuania's membership in the EU. Academic writings have rightly pointed to the fact that the explicit constitutional basis for Lithuania's membership within the EU was missing for more than two months. ${ }^{14}$ Realising the risk of uncertainty and devaluation of the $\mathrm{CA}$, the $\mathrm{CC}$ pre-empted doubts about the constitutionality of, for example, the application of EU regulations between 1 May 2004 and 14 August 2004, and decided to correct the faults of the political process by stating that Lithuania's membership in the EU '... is constitutionally confirmed by the Constitutional Act of the Republic of Lithuania 'On Membership of the Republic of Lithuania in the European Union' [emphasis added].

Finally, in order to remove inconsistencies between certain provisions of the Constitution and EU law, Arts. 47 and 119 were amended before Lithuania acceded to the EU. ${ }^{15}$

1.2.2 The CC makes it clear that the Constitution is an integral act, and all provisions of the Constitution are interrelated to the degree that the content of some provisions of the Constitution determines the content of other provisions. The provisions of the Constitution constitute a harmonious system and no provision of the Constitution can oppose its other provisions, because the nature of the Constitution as an act of supreme legal power and the idea of constitutionality imply that there are not, nor can there be, any gaps or internal contradictions in the Constitution. $^{16}$

On the other hand, the Constitution establishes different procedures and requirements as regards its amendment, thus establishing a certain de facto internal hierarchy of its provisions. These procedures are rather rigid and require wide

not applicable. (Some revisions have been made to the English translation available at http:// www3.lrs.lt/pls/inter3/dokpaieska.showdoc_e?p_id=275302 by the author).

${ }^{14}$ Jarukaitis 2006a, pp. 395-396.

${ }^{15}$ In order to secure the right of foreign nationals to acquire land in Lithuania, Art. 47 of the Constitution was amended twice before accession: in 1996 and in 2003 in order to ensure its full compatibility with EU fundamental economic freedoms. With regard to the right of EU citizens to participate in municipal elections, Art. 119 of the Constitution was amended on 20 June 2002, because originally this right was reserved for Lithuanian citizens only. For more details see: Jarukaitis 2006a, pp. 396-397.

${ }^{16}$ Rulings of 25 May 2004; 13 December 2004; 28 March 2006. 
support both among the public in general and among the political parties represented in Parliament, ensuring that the constitutional amendment procedure is above the ordinary political process.

First of all, according to Art. 148(1), 'the provision of Art. 1 of the Constitution "the State of Lithuania shall be an independent democratic republic" may only be altered by referendum if not less than three-quarters of the citizens of Lithuania with the electoral right vote in favour thereof'. The $\mathrm{CC}$ has recently ruled that Art. 1 of the Constitution consolidates the fundamental constitutional values - the independence of the state, democracy and the republic - which are inseparably interrelated and form the foundation of the State of Lithuania, as the common good of the entire society consolidated in the Constitution; they must not be negated under any circumstances. Further, the Court ruled that the principle of recognition of the innate nature of human rights and freedoms should also be regarded as a fundamental constitutional value that is inseparably related to the constitutional values independence, democracy and the republic - which constitute the foundation of the State of Lithuania as the common good of the entire society consolidated in the Constitution; the innate nature of human rights and freedoms may not be negated either. Given the constitutional imperative to ensure that no amendments of the Constitution violate the harmony of the provisions of the Constitution or the harmony of the values consolidated by them, the Constitution does not permit any such amendment that would deny at least one of the above-mentioned constitutional values underlying the foundations of the State of Lithuania as the common good of the entire society, with the exception of the cases where Art. 1 of the Constitution would be altered (by a referendum with a three-fourths majority). ${ }^{17}$

Amendments of the Constitution concerning other chapters of the Constitution must be considered and voted in the Seimas (the Parliament of Lithuania) twice (of course, it may decide to submit them to a referendum as well, since Art. 9(1) of the Constitution stipulates that the most significant issues concerning the life of the State and the Nation shall be decided by referendum). There must be an interval of not less than three months between the votes. A draft law on amendment of the Constitution shall be deemed adopted by the Seimas if, during each of the votes, not less than two-thirds of the Members of the Seimas vote in favour.

1.2.3-1.2.4 Alongside the above-mentioned constitutional reforms related to Lithuania's membership within the EU, Art. 125 of the Constitution was amended in 2006 by the Parliament. Before amendment, Art. 125 of the Constitution provided for the Bank of Lithuania's 'exclusive right to issue bank notes', which was not in line with the rights of the European Central Bank. The Law amending Art. 125 of the Constitution was adopted on 25 April 2006, and it simply abolished Art. 125(2) of the Constitution.

The CC declared that the Law amending Art. 125 of the Constitution was adopted in breach of the essential procedural requirements of Art. 147 of the Constitution and annulled the law by its ruling of 24 January 2014. Still, the Court

${ }^{17}$ Ruling of 24 January 2014. 
pointed out in the ruling that the Constitution establishes a constitutional imperative of positive geopolitical orientation (that is, membership in the EU and NATO), whereas the Preamble of the CA expressly speaks about the 'fully-fledged participation of the Republic of Lithuania in the European integration'. From this the Court deduced the constitutional obligation of Lithuania to participate as a fully-fledged Member State in the integration of the member countries into the EMU by adopting the common currency and conferring exclusive competence in the area of monetary policy to the EU.

\subsection{Conceptualising Sovereignty and the Limits to the Transfer of Powers}

1.3.1 The CA establishes explicit constitutional provisions concerning both the transfer (or trust, to be more precise) of part of the competences of state institutions to the supranational level (Art. 1 of the CA) and the incorporation of EU law into national law with (limited) recognition of its specific features (Art. 2 of the CA). ${ }^{18}$ Without any doubt, these provisions should be viewed and understood in the context of ongoing discussions and disputes concerning the concept of sovereignty (see Sect. 1.3.2).

Article 1 of the CA establishes a clear constitutional basis for transfer of part of the competences of state institutions to supranational institutions. It may be treated as the exception to the general rule, established in Art. 5 of the Constitution, according to which the exercise of public powers in Lithuania is reserved only for Lithuanian institutions. Thus, it opens the national constitutional order and, alongside the horizontal division of public powers, legitimates the vertical distribution of powers.

It can be said that Art. 1 of the CA adopts a classic approach as regards the exercise of public powers by the EU. In this respect it speaks about 'sharing or entrust of competences' and by doing so emphasises several aspects. First of all, the clause embeds the principle of conferral on which the EU is based at the national constitutional level. The term 'entrusts' ('patiki' in Lithuanian) is to some extent a synonym of the term 'confers', but it is more subtle, since it demonstrates that such conferral is not irreversible and the ultimate source of authority rests at the national level. ${ }^{19}$ In this regard, the provisions of Art. 1 of the CA are similar to the constitutional 'EU clauses' of those EU Member States which have chosen the so-called Belgo-German model, which refers to the transfer of competences instead of the limitation of sovereign powers (like, for example, the Constitution of Italy).

Article 1 of the CA performs several functions. First of all it should be related to the rationalising or defining function of the Constitution, since the Constitution

\footnotetext{
${ }^{18}$ For the wording of the Constitutional Act, supra n. 13.

${ }^{19}$ On the other hand, the Preamble of the CA (rec. 4) expressly recognises the necessity of membership in the EU, since it establishes a connection between the security and welfare of citizens and participation in the EU.
} 
organises and limits the exercise of public power. From this perspective the provisions of Art. 1 serve an integrative purpose, since they open the national constitutional order and allow the exercise of public powers by the EU institutions in the territory of Lithuania, which would not be possible without Art. 1. Of course, such constitutional permission triggers a mutation of other constitutional principles (like democracy (see Sects. 1.4.1 and 1.4.2), separation of powers, etc.).

At the same time, Art. 1 of the Act serves a defensive function. From this perspective it should be read in conjunction with the Preamble of the CA, which establishes certain basic presumptions and subtle constitutional imperatives or conditions for Lithuania's membership within the EU. ${ }^{20}$ Attention should be drawn to the careful language of Art. 1. It speaks not about the renunciation or renouncement of public powers, but about Lithuania 'as a Member State' that 'shares and entrusts' certain competences. The object of such sharing and trust is not sovereignty per se or even 'sovereign powers', but only 'the competences of its State institutions'. ${ }^{21}$ To sum up, the principle of sovereignty, which serves as a basis for Lithuania's membership within the EU (because it could became an EU Member State only because it is a sovereign state from the point of view of public international law), also serves as a conceptual limit to further EU integration: from the point of view of the Constitution of Lithuania, without amendments to Art. 1 of the Constitution, it would not be possible to accept claims on the part of the EU not 'only' to autonomy, which Art. 1 of the CA clearly reflects, but to statehood. Further, the provisions of the Preamble of the CA may be seen as material limits to the exercise of public power also at the EU level.

Article 2 of the CA incorporates EU law into the national legal system, thus to some extent recognising the sui generis nature of EU law. ${ }^{22}$ Without any doubt from the point of view of the national Constitution, after the adoption of Art. 2 of the CA, the basis for the application of EU law rests, foremost, within the Constitution itself. This means that by adopting the CA the Parliament constitutionalised the principles developed by the European Court of Justice (ECJ), i.e. granting these principles special, constitutional treatment, but on the other hand, it rejected the idea that these principles stem from the nature of EU law itself, without the 'mediation' of the national Constitution. Consequently, the adopted CA makes the application of EU law and its specific features a matter of national constitutional

\footnotetext{
${ }^{20}$ According to the Preamble of the CA, the Parliament adopts the CA 'expressing its conviction that the European Union respects human rights and fundamental freedoms and that the Lithuanian membership in the European Union will contribute to a more efficient securing of human rights and freedoms' and 'noting that the European Union respects the national identity and constitutional traditions of its Member States'.

${ }^{21}$ See as well Šileikis 2005, pp. 49-51; Jarukaitis 2006b, pp. 25-26; Vaičaitis 2006, pp. 62-63; Jarukaitis 2010a, pp. 212-214.

${ }^{22}$ Such conclusion follows from the fact that Art. 138(3) incorporates ratified international treaties into the Lithuanian legal order and adopts a monist approach with regard to public international law. Consequently, if EU law were to be treated as part of public international law, the provisions of Art. 2 of the CA would be redundant.
} 
law - which means that the Constitution instead of EU law by its very nature forms the basis for the application of EU law in Lithuania. This leads to some important consequences: EU law becomes part of the national legal system; all state institutions (national courts, other state institutions) have a duty to apply EU law and to interpret national law 'in the light' of EU law as a matter of Lithuanian constitutional law as well, ${ }^{23}$ and the national courts have a constitutional right and duty to use the preliminary ruling procedure. At the same time, it serves a defensive function, since its mere existence rejects the idea of the absolute autonomy of EU law as developed by the ECJ. Moreover, the principle of primacy of EU law does not extend unconditionally over the Constitution of Lithuania (see Sect. 1.3.4).

1.3.2 With regard to sovereignty as a theoretical concept and legal principle, two preliminary remarks should be made. First, it is clear that legal commentators do not agree on the content of the concept of sovereignty. The statement that disagreement and conflict are constitutive elements of the concept of sovereignty, leading to its description as an essentially contestable concept, seems to be quite accurate. ${ }^{24}$ Secondly, taking into account its historic origins and later developments, there is no basis to equate sovereignty and the actual powers performed by a political community. Thus, the author of this report supports the ideas of those who define sovereignty as a sufficiently effective claim to ultimate power in the context of the sovereignty discourse, but nothing more. ${ }^{25}$ Viewed from this perspective, the claim that EU Member states are sovereign is not under challenge, whereas the EU itself has never made such a claim.

Lithuanian authors recognise the relative character of the concept of sovereignty. Even before World War II one of most prominent professors argued that neither the external nor internal aspects of state sovereignty can be treated as absolute, since externally a state is subjected to international law, whereas internally state powers are subject to people's needs. ${ }^{26}$ Contemporary constitutional writings associate the concept of sovereignty with the following dimensions: the self-determination of the people of how to live and the right to establish their own state ${ }^{27}$ the right to make political constitutional decisions independently; the principal existence of the state as a member of the international community alongside other states; ${ }^{28}$ as the

\footnotetext{
${ }^{23}$ The CC so far has not explicitly stated that the national courts have a constitutional duty to apply EU law; however, such duty can be clearly deduced from its recent ruling of 24 January 2014. The Supreme Court of Lithuania has taken this approach e.g. in Decision of 7 January 2008 in Case No. 3K-3-91/2008, and the SAC e.g. in Decision of 28 May 2007 in Case No. A6-238/ 2007 and Decision of 1 October 2010 in Case No. A858-1204/2010. For more details on the application of EU law in Lithuania see, for example, Jarukaitis 2010a, pp. 222-241; Jarukaitis 2010b, pp. 176-202.

${ }^{24}$ Besson 2004, pp. 15-16.

${ }^{25}$ For extensive analysis on the subject see, for example, Werner and De Wilde 2001; Walker 2003, pp. 19-32.

${ }^{26}$ Römeris 1995, p. 245.

${ }^{27}$ Jarašiūnas 2001, p. 496.

${ }^{28}$ Vadapalas 2002, pp. 14-15.
} 
discursive form, through which a political community permanently expresses claims to the supreme public powers; ensuring the continuous identity and independent status of that political community ${ }^{29}$.

The CC has so far been laconic on the content of the principle of sovereignty; ${ }^{30}$ however, its practice confirms a close link between the principles of people's sovereignty, state sovereignty and democracy. In its recent ruling of 24 January 2014, it provided a more detailed approach as regards Lithuania's membership within the EU and the content of the CA. The Court considers membership within the EU to be a reflection of the geopolitical choice of Lithuania, which at the same time is a value choice: the Preamble of the CA clearly reveals that Lithuania's accession to the EU is based on an assumption of the structural compatibility of the fundamental values established in the Constitution with those on which the EU is founded. Additionally, membership within the EU is based on the belief that such membership ensures better preconditions for attainment of the constitutional imperatives established by the Constitution. Further, the $\mathrm{CC}$ has expressly stated that the CA establishes, inter alia, the constitutional grounds for the membership of Lithuania in the EU and that if such constitutional grounds were not consolidated in the Constitution, Lithuania could not be a full member of the EU. In the ruling, the Court made it clear that Arts. 1 and 2 of the CA may be amended only by way of a referendum, and established certain material limits to integration, related to the basic values of the Constitution (see Sect. 1.3.3).

1.3.3 The fundamental limit to the transfer of powers to the supranational level is established in Art. 1 of the Constitution, i.e. Lithuania must remain an independent democratic republic. Recently, the $\mathrm{CC}$ ruled that an inseparable link exists between the independence of the state, democracy, the republic and the innate character of human rights and freedoms. ${ }^{31}$ Therefore, the Constitution does not permit any amendments that would deny at least one of the above-mentioned constitutional values underlying the foundations of the State of Lithuania as the common good of the entire society. In order to overcome such a limitation, Art. 1 of the Constitution should be amended by a referendum as prescribed by Art. 148(1) of the Constitution.

Moreover, the sovereign (the people) is not absolutely free in exercising its powers to amend the Constitution. The CC stressed in its decision of 7 July 2014 that the principle of the rule of law is applicable to the procedure for amending the Constitution. The Court has deemed the pacta sunt servanda principle to be part of the constitutional principle of the rule of law, stating that the Constitution establishes the constitutional imperative to observe and fulfil international obligations

\footnotetext{
${ }^{29}$ Jarukaitis 2011, pp. 163-188.

${ }^{30}$ For example, in its ruling of 19 September 2002, the Court noted, that '[i]n Art. 1 of the Constitution the fundamental principles of the Lithuanian State are established: the Lithuanian State is free and independent; the republic is the form of governance of the Lithuanian State; state power must be organised in a democratic way, and there must be a democratic political regime in this country' (translation by the author).

${ }^{31}$ Decision of 19 December 2012; Ruling of 24 January 2014.
} 
correctly. The Constitution must not have and does not tolerate any gaps or internal contradictions. Consequently, the Constitution does not allow amendments that go against obligations undertaken under international or EU law. In order to introduce such amendments in the Constitution, the international or EU obligations would have to be modified or renounced under the procedures provided by international or EU law. To sum up, theoretically, core constitutional values (including the peoples'/state sovereignty) may be overcome, but the threshold is extremely high.

1.3.4 Commentators are quite unanimous in stating that the primacy of EU law does not extend automatically over the Constitution. ${ }^{32}$ Several arguments support such view. Article 7(1) of the Constitution provides that 'any law or other statute, which is contrary to the Constitution shall be invalid' and establishes the principle of supremacy of the Constitution over all other norms. Article 7 is in Chapter I of the Constitution, the provisions of which may be amended only by way of a referendum. The CA was not adopted by way of a referendum. Further, the travaux préparatoires of the draft $\mathrm{CA}$ and the deliberations in Parliament during the adoption of the CA point in the same direction.

It is also worth noting that there is no need to recognise the unconditional primacy let alone the supremacy of EU law over national constitutions, whether as a matter of the constitutional architecture of the $\mathrm{EU}^{33}$ or as a matter of positive EU law, if one takes into account the constitutional identity clause in Art. 4(2) TEU. ${ }^{34}$

The practice of the CC confirms that it is not ready to accept the unconditional primacy of EU law over the Constitution. In its ruling of 14 March 2006, the Court stated:

... the Constitution consolidates not only the principle that in cases when national legal acts establish the legal regulation which competes with that established in an international treaty, then the international treaty is to be applied, but also, in regard of European Union law, establishes expressis verbis the collision rule, which consolidates the priority of application of European Union legal acts in the cases where the provisions of the European Union arising from the founding Treaties of the European Union compete with the legal regulation established in Lithuanian national legal acts (regardless of what their legal power is), save the Constitution itself [emphasis added].

Although the ruling was interpreted by some authors as a declaration of the unconditional supremacy of the Constitution over EU law, such a conclusion is too extensive, since the Court did not rule explicitly on what the relationship between EU law and the Constitution is. It may be said that the Court simply decided to proceed on a case-by-case basis and to avoid any generalisations.

Such a thesis has been confirmed by the subsequent practice of the Court, which shows its readiness to ensure harmony between the Constitution and EU law. In its ruling of 21 December 2006, the Court took a step forward and, citing decisions of

\footnotetext{
${ }^{32}$ Kūris 2004a, p. 36; Šileikis 2005, p. 143; Abramavičius 2006, p. 313; Jarukaitis 2010a, pp. 225-234.

${ }^{33}$ See, for example, Poiares Maduro 2003, pp. 74-102.

${ }^{34}$ See, for example, Jarukaitis 2014, pp. 575-620.
} 
the Court of First Instance and the ECJ for the first time, noted that ' $[t]$ he Constitutional Court has stated several times that the jurisprudence of the European Court of Human Rights, as a source of legal interpretation, is important for the interpretation and application of Lithuanian law. The same should be said about the jurisprudence of the Court of First Instance and the European Court of Justice' [emphasis added]. This statement may be treated as an explicit recognition of the impact EU law has on national law, including on the Constitution. Of course, it does not eliminate all grounds for a potential conflict, but indicates the Court's willingness to do its best to avoid one.

A further step in developing a friendly approach to EU law was taken on 8 May 2007 when the Court made a reference to the ECJ for a preliminary ruling concerning the interpretation of an EU directive, being one of the few national constitutional courts that has ever used this procedure.

After Lithuania had acceded to the EU, the $\mathrm{CC}$ recognised that the adoption of the CA may trigger the need to reinterpret the Constitution; indeed, the $\mathrm{CC}$ has already started to re-evaluate its practice developed before accession and to identify areas where reinterpretation of the Constitution is needed. ${ }^{35}$

The ruling of 24 January 2014, in which membership within the EU was deemed to be a constitutional value and imperative based on the structural compatibility of the fundamental values of both the Constitution and EU primary law, should be viewed as a clear manifestation of a friendly approach to EU membership and obligations stemming from it. Furthermore, given the above-mentioned proviso 'save the Constitution itself' in the ruling of 14 March 2006 along with the core principles enunciated in the ruling of 24 January 2014, one may speculate that similarly to other constitutional courts of EU Member States, the CC has slowly and implicitly accepted the existence of 'ordinary' constitutional rules, which are more prone to impact by EU law, and the constitutional nucleus, which is more resistant to the influence of EU law.

\subsection{Democratic Control}

1.4.1 Article 3 of the CA regulates the involvement of the Seimas in the EU decision-making process and parliamentary control of the Government when it acts at the EU level. ${ }^{36}$ The provisions of Art. 3 of the CA aim at ensuring a balance between the necessity to have a close involvement of the Parliament when the Government participates in the EU Council with the need to leave enough flexibility for bargaining so the Government can react to what is going on in the EU Council.

\footnotetext{
${ }^{35}$ For example, Ruling of 26 September 2006. For a more detailed description of the CC practice vis-à-vis EU law, see: Jarukaitis 2010a, pp. 225-234; Jarukaitis 2010b, pp. 182-189.

${ }^{36}$ For the wording of the text, see supra n. 13.
} 
Detailed provisions implementing these provisions are established in Chap. $27^{1}$ of the Statute of the Seimas, which has the force of law. ${ }^{37}$

By way of a summary of the provisions, the Statute accords the main powers for parliamentary control to the European Affairs Committee and, in the field of the Common Foreign and Security Policy and other external issues, to the Foreign Affairs Committee, which are given the right to issue opinions on behalf of the Parliament. In some cases the Statute requires discussions to be held (for example, deliberations on the compliance of draft EU legal initiatives with the principle of subsidiarity) not in the European Affairs Committee but in the plenary session. The Government has a duty to inform the Seimas in writing of proposals to adopt EU legal acts and other relevant EU documents. Once the European Commission communicates its annual work programme, the specialised committees of the Seimas identify the priorities for the upcoming year in order to focus on the issues that are most relevant for Lithuania, and the finalised version of these priorities is submitted to the Government. The institution responsible for the preparation of the Lithuanian position concerning a proposal to adopt an EU legal act or other EU document has the obligation to submit the position to the Seimas immediately after its preparation, and no later than three days prior to the debate on this position in the EU institutions. At the executive level, the formation of the Lithuanian position is initiated and conducted through the LINESIS electronic platform, which records all the changes made in the Lithuanian position throughout its preparation.

Once received in the Seimas, the position is forwarded to the specialised committees and to the European Affairs Committee or the Foreign Affairs Committee. Having deliberated on a position, a specialised committee may either approve the position or propose amendments and review of the position; its position is communicated either to the European Affairs Committee or the Foreign Affairs Committee. The position is deliberated at a meeting of the European Affairs Committee or the Foreign Affairs Committee where the Prime Minister or the appropriate minister presents the position and answers questions; the conclusions of the specialised committees are presented and discussions on the position are held. The committee decides by consensus or by a vote whether it should, on behalf of the Seimas, state its opinion about the position. If so, the chair of the meeting proposes the wording of the opinion, and the opinion is adopted in a vote. Both committees may oblige a minister to maintain a parliamentary reservation during the deliberation of issues that are considered as highly relevant or relevant in the EU institutions. Art. $180^{17}$ establishes the obligation of the Prime Minister and ministers to submit an oral or written report on the fate of the Lithuanian position after the relevant meeting of the European Council or the EU Council.

Additionally, Art. $180^{6}$ of the Statute establishes a subsidiarity control procedure, according to which draft EU legislation is scrutinised by the specialised committees and their positions are submitted to the European Affairs Committee or

\footnotetext{
${ }^{37}$ The English translation of the Statute is available at http://www3.lrs.lt/pls/inter3/dokpaieska. showdoc_l?p_id=473761.
} 
the Foreign Affairs Committee. If one of these Committees decides that a draft EU law does not respect the principle of subsidiarity, it prepares a draft Seimas resolution with a reasoned opinion. The resolution is debated by the Seimas sitting in accordance with the special urgency procedure. If adopted, the Seimas resolution regarding the reasoned opinion is forwarded to the Government.

To sum up, the system put in place seems to function rather effectively; there is quite a high degree of information exchange and harmonisation of positions between the Government and the Parliament. In practice, the Parliament's role in the EU decision-making process is quite important.

1.4.2 According to Art. 9 of the Constitution, the most significant issues concerning the life of the State and the Nation shall be decided by referendum. Article 4(5) of the Law on Referendums provides for a mandatory referendum concerning the participation of the Republic of Lithuania in international organisations 'should this participation be linked with the partial transfer of the scope of competence of Government bodies to the institutions of international organizations or the jurisdiction thereof'.

Needless to say, Lithuania's accession to the EU had a profound impact on the whole society, the state and the core constitutional principles of the national polity. Consequently, it was decided that a referendum would be held on EU accession once the Accession Treaty was signed. The referendum took place on 10-11 May 2003; a simple statement 'I am for Lithuania's membership in the European Union' was submitted to a vote. Of citizens with the right to vote, $63.37 \%$ participated in the referendum, of whom a notably high $90 \%$ voted in favour of Lithuania's accession to the EU. From the point of view of democratic legitimacy, the referendum was of utmost importance, especially because of the far-reaching consequences of EU membership.

This was the first referendum related to EU issues. There were calls to hold a referendum concerning the ratification of the Treaty establishing a Constitution for Europe; however, ultimately it was decided that the Treaty would be ratified by Parliament.

Two unsuccessful referendum initiatives related to EU membership were promoted in 2013-2014. One concerned a proposed amendment of Art. 47 of the Constitution, aimed at restricting the right of foreigners to buy land in Lithuania. ${ }^{38}$ The second initiative concerned the proposed amendment of Art. 125 of the Constitution and Art. 1 of the CA. The initiators proposed amending the Constitution in order to re-establish the right of the Bank of Lithuania to emit bank notes. The Central Electoral Commission refused to register the initiative, arguing that such amendments would not be compatible with the Constitution. The Supreme Administrative Court of Lithuania (hereinafter SAC), after verifying with the CC whether the Central Electoral Commission had such authority under the

\footnotetext{
${ }^{38}$ The referendum took place on 29 June 2014 and failed, as only $14.98 \%$ of eligible voters participated (instead of the required 50\%).
} 
Constitution, ${ }^{39}$ supported the findings of the Central Electoral Commission on 18 July 2014. ${ }^{40}$ The Court, relying inter alia on the jurisprudence of the CC, concluded that Lithuania has the obligation, stemming both from the Accession Treaty as well as from the Constitution, to introduce the euro. Therefore, in order to introduce the proposed amendments to the Constitution, prior amendment of the Accession Treaty would be needed. ${ }^{41}$

\subsection{The Reasons for, and the Role of, EU Amendments}

1.5.1-1.5.3 It is obvious that the above-mentioned constitutional amendments related to Lithuania's membership in the EU were necessary, because otherwise such membership would not be compatible with the Constitution (this argument is first and foremost addressed to provisions establishing the constitutional basis for the transfer of part of the public powers to the supranational level). One of the main functions of the Constitution - the establishment, organisation and limitation of public power - means that only the exercise of public power sanctioned by the Constitution is legitimate. Before the adoption of the CA, the exercise of public powers was reserved for national institutions only. Therefore, to legitimise the transfer of vast public powers to the supranational level, which itself triggered fundamental changes to some core constitutional principles (democracy, separation of powers, the rule of law, the role of the Constitution and constitutional review, etc.) an appropriate constitutional authorisation was needed. Otherwise, the gap between the text of the Constitution and the 'real' Constitution (that is, the actual modus vivendi within a national polity) would have become too wide, leading to a sharp decrease in the legitimacy of public power. There was a near-unanimous agreement among legal scholars in Lithuania before accession to the EU that EU related amendments were necessary; the main discussions revolved around the optimal form and content of such amendments. The expert groups that drafted the constitutional amendments analysed and took into account the experience of some of the 'old' Member States, which at that time had similar constitutional provisions.

Moreover, the Constitution is an anti-majoritarian act, established to protect the fundamental rights and liberties of the individual; therefore, given the overall

\footnotetext{
${ }^{39}$ Ruling of the CC of 11 July 2014 . The argument was presented, in the proceedings before the SAC, that Lithuanian law does not give the right to the Central Electoral Commission to refuse to register a referendum initiative, since such refusal would unduly restrict the constitutional right of self-determination. Therefore, the SAC decided to clarify this aspect and to refer the issue to the $\mathrm{CC}$. The $\mathrm{CC}$ rejected this argument in its ruling and decided that the law establishing such right of the Central Electoral Commission does not contravene the Constitution of Lithuania.

${ }^{40}$ Ruling of the SAC of 18 July 2014 in Case No. R-858-11-14.

${ }^{41}$ Lithuania joined the eurozone on 1 January 2015.
} 
constitutional architecture of the EU (Art. 4 of the TEU in particular), the Constitution should be treated as the guarantor of those rights despite the transfer of public powers to the supranational level.

\section{Constitutional Rights, the Rule of Law and EU Law}

\subsection{The Position of Constitutional Rights and the Rule of Law in the Constitution}

2.1.1 One of the primary functions of the Constitution is to protect the fundamental rights and freedoms of individuals. According to Art. 18 of the Constitution, human rights and freedoms are innate. Although Art. 18 of the Constitution is not technically in Chapter I of the Constitution, which may be amended only by way of a referendum, the $\mathrm{CC}$ has ruled that the innate nature of fundamental rights and freedoms is inseparable from the other fundamental provisions of the Constitution established in Art. 1 (the independence of the state and democracy). Therefore, according to the CC, Art. 18 may be amended only by a referendum in which the supermajority envisaged for amendments to Art. 1 of the Constitution is required. ${ }^{42}$ Chapter II of the Constitution establishes traditional civil and political rights in detail. Pursuant to Art. 6(2) ('Everyone may defend his rights by invoking the Constitution') and Art. 30(1) ('[Any] person whose constitutional rights or freedoms are violated shall have the right to apply to [a] court'), constitutional rights and freedoms are directly enforced by the Lithuanian courts.

Although the principle of the rule of law (in Lithuanian 'teisines valstybes principas') and its various manifestations (like legal certainty, legitimate expectations, etc.) are not explicitly enshrined in the Constitution (apart from the Preamble of the Constitution, which speaks of the Lithuanian nation 'striving for an open, just, and harmonious civil society and State under the rule of law'), the practice of the CC clearly confirms that the rule of law is a core structural principle penetrating all aspects of the Constitution and, as such, is justiciable in the courts (see Sect. 2.1.3).

2.1.2 The Constitution does not contain any specific provisions establishing general conditions under which restrictions of fundamental rights and freedoms may be imposed. However, different articles of the Constitution establish various grounds for derogation, for example, Art. 20 ('No one may be deprived of his freedom otherwise than on the grounds and according to the procedures which have been established by law'); Art. 22 ('Information concerning the private life of a person may be collected only upon a justified court decision and only according to the law'); Art. 25 ('Freedom to express convictions, to receive and impart information may not be limited otherwise than by law, if this is necessary to protect the health,

${ }^{42}$ Ruling of 24 January 2014. 
honour and dignity, private life, and morals of a human being, or to defend the constitutional order'), etc. The CC has in its practice developed a general standard for limitations of fundamental rights and freedoms. According to the Court, under the Constitution, the restriction of fundamental rights and freedoms is permitted if all the following conditions are met: the limitation is imposed by a law adopted by Parliament; these restrictions are necessary in a democratic society in order to protect the rights and freedoms of other persons as well as the values established in the Constitution together with constitutionally important objectives; the restrictions must not deny the nature and essence of the rights and freedoms; and the constitutional principle of proportionality is observed. ${ }^{43}$

2.1.3 The rule of law (a state governed by law) is treated as the cornerstone principle of the entire national constitutional system. Although not expressly established in any particular article of the Constitution, the principle transfuses many core provisions of the Constitution. These include Art. 1, ('The State of Lithuania shall be an independent democratic republic'); Art. 5(2) ('The scope of power shall be limited by the Constitution'); Art. 6(1) ('The Constitution shall be an integral and directly applicable act'); and Art. 7 ('Any law or other act, which is contrary to the Constitution, shall be invalid. Only laws which are published shall be valid').

Lithuanian authors are unanimous in treating the rule of law as an independent (constitutional) legal principle, which co-ordinates and determines the whole (constitutional) legal system; various elements of the principle are among the most important factors ensuring the proper unfolding of the Constitution. ${ }^{44}$

The CC consistently points out that the principle of the rule of law is a universal legal principle upon which the whole Lithuanian legal system as well as the Constitution itself are based, and that the content of the principle is revealed in various provisions of the Constitution. It is construed as inseparable from striving for an open, just, and harmonious civil society and law-governed state, as promulgated in the Preamble of the Constitution. Along with other requirements, the principle also pre-supposes that human rights and freedoms must be ensured, that all state institutions exercising state power and other state institutions must act on the basis of and in compliance with the law, that the Constitution has supreme juridical force and that all legal acts must be in conformity with the Constitution. ${ }^{45}$

The CC has in its practice identified different elements of the rule of law, which include the following: rules of general application must be established by laws passed by the Parliament; the supremacy of laws and hierarchy of different legal acts, which are all subordinated to the Constitution; the accessibility of legal provisions; legal certainty and the integrity of law; nullum crimen, nulla poena sine lege; natural justice; due process of law; the independence and impartiality of

\footnotetext{
${ }^{43}$ See e.g. Ruling of 14 March 2002.

${ }^{44}$ Kūris 2001, pp. 241-254; Šileikis 2005, pp. 198-210.

${ }^{45}$ For example, the Rulings of 23 February 2000, 11 January 2001.
} 
judges and courts; legitimate expectations; proportionality; and the constitutional imperative to observe the public international law principle pacta sunt servanda.

As one may see, the principle has extensive content. The CC treats the principle as one of utmost importance for the systemic interpretation of various constitutional provisions, even if it has not been singled out as one of the core constitutional principles that can only be renounced under the Art. 148(1) procedure. ${ }^{46}$ Furthermore, the principle itself is justiciable and applicants may challenge legal provisions as regards their compatibility with the principle. Recently, the CC went so far as to say that the rule of law binds the sovereign (that is, the people) itself in that it does not allow for the introduction of constitutional amendments that would contravene Lithuania's international obligations or obligations stemming from EU law. In order to introduce such constitutional provisions, international or EU obligations would have to be renounced or modified in a way that would not contradict the proposed amendments. ${ }^{47}$

\subsection{The Balancing of Fundamental Rights and Economic Freedoms in EU Law}

2.2.1 No constitutional issues have so far been raised in Lithuania with regard to the impact of EU economic freedoms on constitutional civil, political or social rights in court practice or in academic writings.

In the Expert's view, the ECJ has so far been careful to give the Member States wide discretion in this field (see, for example, the Schmidberger, Omega and Dynamic Medien judgments). ${ }^{48}$ The Laval and Viking Line cases ${ }^{49}$ are very specific and on their own should not be treated as a confirmation of the ECJ's approach that EU economic freedoms should generally be given priority over social rights. The Member States which intervened in these cases had very different views on the subject. It seems that at least in the Laval case, the outcome was to some extent predetermined by the existence of Lex britannia (i.e. the Swedish court practice, according to which there is no 'peace' if a collective agreement is concluded with a non-Swedish trade union) and the opaqueness of the negotiation process, especially for the economic entities that were not used to operating in the Member State in question. Further, the comparison of balancing economic with other rights at the national level and balancing EU economic freedoms with other rights at the EU

\footnotetext{
${ }^{46}$ Some authors argue that the rule of law is inseparable from other core constitutional principles: Šileikis 2005, p. 199.

${ }^{47}$ Ruling of 11 July 2014.

${ }^{48}$ Case C-112/00 Schmidberger [2003] ECR I-05659; Case C-36/02 Omega [2004] ECR I-09609; Case C-244/06 Dynamic Medien [2008] ECR I-00505.

${ }^{49}$ Case C-345/05 Laval un Partneri [2007] ECR I-11767; Case C-438/05 The International Transport Workers' Federation and The Finnish Seamen's Union [2007] ECR I-10779.
} 
level to some extent is not appropriate, since EU economic freedoms have an integrative function, thus by definition they seek to remove certain national restrictions. Finally, when the Lisbon Treaty came into force the legal landscape changed completely, with Art. 3(3) TEU explicitly noting the social orientation of the EU market economy, and the Charter of Fundamental Rights of the EU (Charter) covering social rights as well.

\subsection{Constitutional Rights, the European Arrest Warrant and EU Criminal Law}

\subsubsection{The Presumption of Innocence}

2.3.1.1 Article 31 of the Constitution states that '[e]very person shall be presumed innocent until proved guilty according to the procedure established by law and declared guilty by an effective court judgment'. A similar rule is contained in Art. 44 of the Code of Criminal Procedure (CCP): 'Anyone charged with a criminal offence shall be presumed innocent until proved guilty in accordance with a procedure prescribed by this Code and established by an effective court judgment.' In addition, Art. 2 of the CCP prescribes that '[e]very time when elements of a criminal act are discovered, the prosecutor and the institutions of pre-trial investigation shall, within the limits of their competence, take all measures provided for by law to conduct a pre-trial investigation and ascertain that the criminal act has been committed'.

The content of the presumption of innocence has been analysed in detail and in various contexts in the jurisprudence of the CC. For example, the presumption of innocence has a much broader content and cannot be attributed solely to criminal legal relations. ${ }^{50} \mathrm{~A}$ further dimension of this principle, which was identified in the jurisprudence of the $\mathrm{CC}$, is that

[i]t is especially important that state institutions and officials follow the presumption of innocence, that public persons should in general restrain from referring to a person as a criminal until the guilt of the person in committing the crime is proven [pursuant to] the procedure established by the law and [the person is found] guilty by an effective court judgment, otherwise, human honour and dignity could [be] violated and human rights and freedoms could be undermined. ${ }^{51}$

On the other hand, the constitutional principle of the presumption of innocence has never been analysed by the $\mathrm{CC}$ in the context of the European Arrest Warrant (EAW).

Various aspects of the principle of the presumption of innocence (for example, 'the burden of proof lies with state officials'; 'any doubts are treated in favour of the

\footnotetext{
${ }^{50}$ Rulings of 29 December 2004 and 25 November 2011 of the CC.

${ }^{51}$ Ruling of 16 January 2006.
} 
defendant'; 'a conviction cannot be based on assumptions', etc.) have been analysed in the jurisprudence of the European Court of Human Rights, ${ }^{52}$ the jurisprudence of the Supreme Court of Lithuania ${ }^{53}$ and the theory of Lithuanian criminal procedure ${ }^{54}$. On the other hand, according to the doctrine of Lithuanian criminal procedure, the content of the principle of presumption of innocence is not precise and determined, and there is no exhaustive list of cases and situations in which this principle has implications for making legal decisions. ${ }^{55}$ At the same time, it should be emphasised that the compatibility issue between the EAW and the principle of the presumption of innocence (as well as other aspects of the constitutionality of the EAW) have not been mentioned either in the jurisprudence of the Supreme Court of Lithuania or in legal commentary in Lithuania. As the author of this part of the report has noted elsewhere, one of the reasons why the question of the constitutionality of the EAW has never been raised in the constitutional jurisprudence or judicial practice of Lithuania is that Lithuania did not participate in the drafting, development or adoption of the Framework Decision on the EAW, ${ }^{56}$ but was required to implement it in national law in order to join the European Union. ${ }^{57}$

It is worth noting that there are some cases in Lithuanian jurisprudence where the advocates of the accused, against whom an EAW was issued, have appealed the extradition arguing that the presumption of innocence has been violated. $^{58}$ However, there are no court decisions refusing to surrender a person to a requesting state specifically because of violation of this principle.

In the opinion of the Expert, it is not as of yet possible to provide an accurate answer to the question whether the principle of the presumption of innocence can no longer fully be granted the same level of protection as prior to the entry into force of the EAW Framework Decision (EAWFD). Moreover, a court decision (concerning an EAW) is essentially a procedural decision that does not solve the question of the guilt of the surrendered person. The Expert has elsewhere expressed the opinion that 'the executing Member State should not control the procedural safeguards and respect for the rights of defence in the issuing Member State because all Member States are parties to the European Convention on Human Rights (ECHR). Moreover, such control would in some sense defy the spirit of the

\footnotetext{
${ }^{52}$ See ECtHR decisions Butkevicius v. Lithuania, no. 48297/99, ECHR 2002-II (extracts) and Daktaras v. Lithuania, no. 42095/98, ECHR 2000-X.

${ }^{53}$ Rulings of the Supreme Court of Lithuania in criminal cases No. 2K-218/2010; 2K-374/2010; 2K-393/2010; etc.

54 Švedas and Merkevičius 2013, pp. 440-441; Goda et al. 2011, pp. 50-52; Jurka et al. 2009, pp. 106-115.

55 Goda 2003, p. 92.

${ }^{56}$ Council Framework Decision of 13 June 2002 on the European arrest warrant and the surrender procedures between Member States (2002/584/JHA), [2002] OJ L 190/1.

57 Švedas 2008, p. 66.

58 The Court of Appeal of Lithuania ordered that the allegations in the EAW were 'sufficiently clear and ... without prejudice to the presumption of innocence'. See the Ruling of Court of Appeal of Lithuania of 26 October 2010, No. 1N-67/2010.
} 
EU, as only such states, which inter alia ensure and safeguard human rights and freedoms, can become members of the EU' ${ }^{59}$

2.3.1.2 It should be noted that review of EAW requests is much more complex in Lithuania. First of all, the review of an EAW is carried out by a prosecutor from the Prosecutor General's Office. This review includes a systematic assessment of the following categories of information: (1) that the form of the EAW is properly constructed in that it bears the appropriate signatures and seals; (2) that the facts of the offence(s) in section (e) of the form are adequately completed; (3) that the facts and legal description of the offence(s) correspond to the double criminality requirement or that the offence set out is properly included in the FD list of 32 categories of crimes; (4) that the sentences mentioned (in a conviction under an EAW) match those handed down by the court; (5) that the identification evidence/ information is deemed to be adequate; and (6) whether grounds for mandatory or optional refusal are apparent from the facts disclosed. ${ }^{60}$

Additional ad hoc enquiries can be made by the prosecutor with regard to individual cases. For example, the Prosecutor General's Office has reported ${ }^{61}$ that it has on two occasions made enquiries of fact to the issuing Member States in two cases of an alleged alibi. ${ }^{62}$ In one case the issuing Member State, having reviewed the case and discovered that there was merit in the claim, withdrew the EAW. In the other case, the issuing Member State found the alibi to be false and the surrender proceeded.

Once a prosecutor from the Prosecutor General's Office verifies that an issued EAW meets all the listed requirements, the prosecutor submits an application regarding the requested person's surrender to the Regional Court of Vilnius in accordance with Art. 73 of the CCP.

Normally the courts follow the principle of a high level of confidence between Member States. For example, the Court of Appeal of Lithuania in ruling No. 1N-36/

\footnotetext{
59 Švedas and Mickevičius 2009, p. 350.

${ }^{60}$ Article $9^{1}$ of the Criminal Code has provided for some additional grounds for non-execution, which are not explicitly included in the FD: (a) a mandatory human rights clause; (b) an optional ground 'where the information contained in the EAW is insufficient to decide the surrender and the issuing judicial authority fails to provide it within the prescribed time limit'; (c) some listed grounds for refusal have been implemented more broadly than they are formulated in the FD, e.g. not only amnesty, but also pardon, etc.

${ }^{61}$ Fourth round of mutual evaluations 'Evaluation of the practical application of the European Arrest Warrant and corresponding surrender procedures between Member States', Report on Lithuania by Multidisciplinary Group on Organised Crime (doc. 12399/2/07 REV 2 CRIMORG 134 COPEN 121 EJN 25 EUROJUST 45), p. 19.

${ }^{62}$ The courts considered that in cases where (e.g.) alibi defences were raised, it would be prudent to make further enquiries to the issuing Member State. If such alibi evidence stood up to examination, the EAW was unlikely to be maintained and so the process could be terminated by the issuing Member State itself, thus preventing the surrender of a requested person in circumstances in which it would be contrary to the interests of justice to pursue the request. However, there have been no judicial refusals of EAWs on this ground. Report on Lithuania, supra n. 61, p. 22.
} 
2007 of 30 August 2007, whereby J. M. was surrendered to Hungary, noted as follows:

Paragraph 10 of the Preamble of the FD on the EAW states that the mechanism of the EAW is based on a high level of confidence between Member States. Its implementation may be suspended only in the event of a serious and persistent breach by one of the Member States of the principles set out in Article $6 \mathrm{EU}$, determined by the Council pursuant to Article 7(1) EU with the consequences set out in Article 7(2) thereof. Such circumstances have not been identified and the implementation of the mechanism of the EAW has not been suspended.

In another ruling (No. 1N-4/2008, dated 8 January 2008), where by A.D. was surrendered to Estonia, the Court of Appeal held that

[d]ifferently to requests for extradition, it is not required to provide the information substantiating the accusation in the case of requests to surrender under the EAW. Competent judicial authorities of the executing state have to trust the information received from the issuing judicial authorities and believe that it has been substantiated by specific data of the criminal case file. Therefore, the claims contained in the request expressed during the court hearing by A.D. to check the case information on the amount of narcotic substances and the facts [regarding validity of his] Russian visa, as well as the requests of the defence counsel to produce thorough evidence of guilt shall be refused.

In principle, the Regional Court of Vilnius must carry out the same review as the prosecutor. According to the Regional Court of Vilnius, the Court does not normally check for double criminality if the offence is on the list of the 32 criminal offences, and does not investigate the circumstances of the crimes or evidence of the guilt underlying an EAW. ${ }^{63}$ For the issuing state it is enough to prove that according to its laws, the offence is on the list of the 32 criminal offences $^{64}$ and is punishable in the state by a custodial sentence or a detention order for a maximum period of at least three years. The court deciding on the EAW usually checks: (1) whether the EAW complies with the EAW form and content requirements; and (2) whether there are grounds on which transfer of the person to another EU Member State should be refused. Depending on the outcome of this check, the court will only verify that no mistakes have been made (for example, if the offence is on the list of 32 criminal offences although it should not be included in the list, given the description of the offence). In cases where a question as to whether a crime has been rightly 'ticked' as a 'listed offence' by the issuing authority arises, the prosecutor or court may ask for additional information from the issuing authority. An omission by the issuing authority may result in the non-execution of the foreign decision on the grounds of 'not enough information'.

\footnotetext{
${ }^{63}$ Rulings of the Court of Appeal of Lithuania in criminal cases No. $1 \mathrm{~N}-48 / 2008 ; 1 \mathrm{~N}-4 / 2008$.

${ }^{64}$ The question as to whether a crime is reasonably placed in a certain category is not elucidated in the national legal provisions. However, it may be presumed that if the executing authority were to discover that the legal description of a committed offence was manifestly incorrect and could not be described as one of the categories of ' 32 listed crimes', it would be forced to take a negative decision on recognition of the issued EAW or other mutual recognition instrument. Thus, in practice, Lithuanian authorities usually require a full description of the offence even if it is a 'listed offence'. For example, see Švedas and Mickevičius 2009, p. 344.
} 


\subsubsection{Nullum crimen, nulla poena sine lege}

2.3.2.1 The principle of nullum crimen, nulla poena sine lege is set out in Art. 31 of the Constitution: 'Punishment may be imposed or applied only on the grounds established by law'. Article 2 of the Criminal Code of the Republic of Lithuania states that

[o]nly a person whose act as committed corresponds to a definition of a ... crime or misdemeanour provided for by a criminal law shall be liable under the criminal law. Penalties, penal or reformative sanctions and compulsory medical treatment shall be imposed only in accordance with the law.

Concerns about the compatibility between the principle of nullum crimen, nulla poena sine lege and the EAW have still not been raised in Lithuanian legal practice or in $\mathrm{CC}$ case law. ${ }^{65}$

It should be noted that in the negotiations on other EU instruments based on mutual recognition (e.g. the draft Framework Decision on the application of the principle of mutual recognition to custodial sentences, which initially did not provide for the rule on double criminality), Lithuanian representatives have usually been consistent in pursuing the position that double criminality (at least for crimes that do not fall into the category of the 32 'listed offences') is a prerequisite for mutual recognition.

However, in the theory of Lithuanian criminal law, questions have arisen with regard to the compatibility of the principle of nullum crimen sine lege and withdrawal (abolition) of the rule of double criminality. It is worthy of note that with regard to the exception of the 32 'listed offences', a question has been raised in the legal commentary as to whether exclusion from the rule of double criminality would be in conformity with the constitutional principles of equality of individuals before the law and their legitimate expectations, as well as with nullum crimen sine lege. Such a question arises in two situations: if Lithuania executes an EAW issued by another state (1) on the ground of an offence which is not fully (or partly) prohibited under the Lithuanian Criminal Code, e.g. in the case of counterfeiting and piracy of products, illicit trafficking in hormonal substances and other growth promoters, or (2) on the ground of any other of the 32 listed criminal offences, where the elements of such offence according to the laws of the requesting state lead to the criminalisation of a broader scope of actions than those covered by the Lithuanian Criminal Code. This theoretical conflict lies in the fact that Lithuania, by executing such an EAW, would be forced to apply coercive measures (e.g. detention, property seizure or other remand measures, etc.) provided for in criminal procedural law for an act that is not prohibited in Lithuania. In other words, if the act were committed in Lithuania, the person in question would not be subject to the coercive measures laid down in the law of criminal procedure and/or criminal law. ${ }^{66}$

\footnotetext{
${ }^{65}$ See Sect. 2.3.1.1 for an explanation of the reasons for this tendency.

${ }^{66}$ Švedas 2008, pp. 67-68; Švedas 2010, pp. 944-945.
} 
It should be noted that research shows that the identical constitutional problems (since the constitution does not allow for cooperation in relation to acts that do not constitute an offence in national criminal law) are faced by $25 \%$ of the Member States, and the identification of offences for which double criminality in the other Member State is no longer relevant is problematic in $92 \%$ of the Member States. ${ }^{67}$

This theoretical conflict with the constitutional provisions can be disproved only by the CC. However, it has not yet heard any cases of this nature.

It should be noted that the question regarding the issue of retroactive amendment of substantive criminal law still has not emerged either in judicial practice or in the theory of Lithuanian criminal law.

The conclusion may be drawn by the Experts that the principle of nullum crimen sine lege, nulla poena sine lege can no longer fully be granted the same level of protection as prior to the entry into force of the EAWFD (especially in accordance with the two previously-mentioned cases).

\subsubsection{Fair Trial and In Absentia Judgments}

2.3.3.1 Article 31 of the Constitution states that '[a] person charged with the commission of a crime shall have the right to a fair public hearing of his case by an independent and impartial court'. This constitutional provision grants the accused person the right to participate in the court hearing. ${ }^{68}$

Article 246 of the CCP provides for one case allowing in absentia proceedings (judgments) in Lithuania: 'The hearing in the court of first instance is conducted in the presence of the accused. The accused person must appear in court. Proceedings in the absence of the accused shall be allowed only if the accused is not in the Republic of Lithuania and avoids appearing in court' ${ }^{69}$ This exception is not absolute, as Art. 433 of the CCP provides that the trial is to be postponed if the case cannot be properly resolved without the presence of the accused.

Despite the quite rare application of Chapter XXXII (including Art. 433) of the $\mathrm{CCP}$ in practice and its exceptional nature in the CCP, there have been no theoretical discussions about in absentia proceedings (as well as EAW judgments in absentia) conflicting with constitutional provisions in Lithuania. On the contrary, in the doctrine of Lithuanian criminal procedure some proposals have been put forward to expand the grounds for proceedings in absentia in the context of the EAW; for example, to amend certain provisions of the CCP to legitimise the following institutes: judgments in absentia for misdemeanours, negligent crimes, and non-serious or semi-serious premeditated crimes. ${ }^{70}$

\footnotetext{
${ }^{67}$ Vermeulen et al. 2012, pp. 127-128.

${ }^{68}$ Goda et al. 2011, p. 597.

${ }^{69}$ Translation by the author.

70 Švedas 2008, p. 72.
} 
It should be noted that Council Framework Decision 2009/299/JHA amending the in absentia trial rules set out in previous framework decisions ${ }^{71}$ has been transposed into the Lithuanian legal system by the amendments of the Criminal Code and CCP of 30 May 2013, using the same wording as in the relevant provisions of the Framework Decision.

The Experts draw the conclusion that the standard of protection remains at the same level in ordinary criminal proceedings and EAW proceedings in absentia. However, in EAW proceedings it is important to: (1) secure for a person convicted in absentia the right to review the case (pending against him) in his physical presence, and (2) ensure a real defence in such proceedings.

\subsubsection{The Right to a Fair Trial - Practical Challenges Regarding a Trial Abroad}

2.3.4.1 Article 13 of the Constitution provides that ' $[t]$ he State of Lithuania shall protect its citizens abroad. It shall be prohibited to extradite a citizen of the Republic of Lithuania to another state unless an international treaty of the Republic of Lithuania establishes otherwise'. ${ }^{72}$

Article 18 of the Law on Consular Statute provides as follows:

If a citizen of the Republic of Lithuania is being detained or is serving a sentence or is suspected of having committed a criminal act in a consular district, a consular officer shall ... contact or, where necessary, meet this person upon a justified request from him, his authorised representative, his spouse (cohabitee) or close relatives. Upon the request of a citizen of the Republic of Lithuania, a consular officer shall ascertain that the citizen has been provided with a defence counsel and other legal aid in accordance with the local laws and that he has been provided with a translator, and where necessary, arrange for the legal aid and translator to be provided. A consular officer shall, where possible, keep in contact with the citizen of the Republic of Lithuania who is serving a sentence of imprisonment and shall ascertain that the conditions of detention of the citizen of the Republic of Lithuania are not worse than those of the citizens of the host State.

A special safeguard for citizens and permanent residents is established in Art. $9^{1}$ of the Criminal Code, which subjects surrender to the condition that the person against whom the issuing Member State has delivered a judgment will be returned to Lithuania to serve the custodial sentence at the request of the person surrendered or where the Prosecutor General's Office of the Republic of Lithuania so requires. Lithuania has chosen not to enact domestic legislation to regulate such surrender of

\footnotetext{
${ }^{71}$ Council Framework Decision 2009/299/JHA of 26 February 2009 amending Framework Decisions 2002/584/JHA, 2005/214/JHA, 2006/783/JHA, 2008/909/JHA and 2008/947/JHA, thereby enhancing the procedural rights of persons and fostering the application of the principle of mutual recognition to decisions rendered in the absence of the person concerned at the trial, [2009] OJ L 81/24.

72 This constitutional provision has been established in the Constitution from the adoption of the Constitution by citizens of the Republic of Lithuania in the Referendum of 25 October 1992.
} 
its own nationals, rather it relies upon the provisions of the 1983 Convention on the Transfer of Sentenced Persons. ${ }^{73}$

Article 51 of the CCP provides that the assistance of a defence lawyer is mandatory in the proceedings when deciding on a person's extradition or surrender to the International Criminal Court or under an EAW. Article 12 of the Law on State-Guaranteed Legal Aid provides that persons falling within the scope of Art. 51 are eligible for secondary legal aid regardless of their property and income levels.

These are the common rules regarding the assistance that Lithuania provides to all its citizens (inter alia extradited citizens or residents). The laws do not provide for the possibility to recover travel expenses.

According to the available information, there are no public or non-governmental organisations providing assistance to extradited persons in Lithuania. These questions generally belong to the duties of the consulate of the state. The Experts would support a recommendation to introduce a publicly funded state or non-governmental body to provide assistance to residents who are involved in trials abroad. However, this question should be the subject of an individual study on, for example, the competence of such body, etc.

There should be mention of the opposite side of the question - recovering the costs of the transfer process in EAW proceedings. The statistical data shows that the state has recovered the costs of the transfer process from 35 (2007), 14 (2008), 43 (2009), 20 (2010), 30 (2011) and 40 (2012) persons who have been transferred, corresponding to a sum of approximately 56000 LTL to 264467 LTL ( 18 200 76000 EUR) per year. This policy of the state has received a lot of criticism, because it unreasonably extends the definition of the costs of criminal proceedings and raises serious doubts about the compliance of this policy with human rights and freedoms standards and the statutory requirements of Lithuania. ${ }^{74}$ The view that the recovery of the costs of the transfer process in EAW or extradition proceedings from transferred persons conflicts with, inter alia, the statutory requirements of Lithuania has been confirmed by the Court of Appeal of Lithuania. The Court of Appeal of Lithuania $^{75}$ has emphasised that

the ensuring of costs for material/in-house provisions, health care, catering and other costs related to the maintenance of such persons shall be the responsibility of the state. Such provisions are established in Chapter XIV of the Punishment Enforcement Code of the Republic of Lithuania and in Section 5 of the Law on Detention of the Republic of Lithuania. The status of a person surrendered under extradition or transferred for criminal prosecution to the Republic of Lithuania is a detained person because a court order to impose a remand measure - detention - has been rendered in regard to him/her. It means that all costs related to the material/in-house provisions for this person are the responsibility of the state. ... Meanwhile other costs related to the execution of extradition are related to

\footnotetext{
${ }^{73}$ Report on Lithuania, supra n. 61, p. 23.

74 Švedas 2008, p. 72.

${ }^{75}$ Ruling of the Court of Appeal of Lithuania of 1 June, 2012, No. 75/2012. Translation by the author.
} 
Table 1 Statistics on the Operation of the EAW 2005-2011 in Lithuania

\begin{tabular}{|c|c|c|c|c|c|c|c|}
\hline Data on the EAW & 2005 & 2006 & 2007 & 2008 & 2009 & 2010 & 2011 \\
\hline 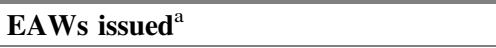 & 500 & 538 & 316 & 348 & 354 & 402 & 420 \\
\hline $\begin{array}{l}\text { Transferred to Lithuania under an } \\
\text { issued EAW }\end{array}$ & 68 & 62 & 117 & 119 & 108 & 138 & 169 \\
\hline $\begin{array}{l}\text { Sentenced persons transferred to } \\
\text { Lithuania, including: }\end{array}$ & 48 & 50 & 59 & 25 & 58 & 31 & 42 \\
\hline Imprisonment & 31 & 22 & 42 & 10 & 38 & 21 & 29 \\
\hline Fine & 10 & 13 & 14 & 7 & 11 & 5 & 2 \\
\hline Other penalty & 7 & 15 & 3 & 8 & 9 & 5 & 11 \\
\hline $\begin{array}{l}\text { Process terminated due to } \\
\text { acquittal }^{c} \text {, amnesty, expiry of limitation } \\
\text { period, reconciliation }\end{array}$ & 6 & 7 & 5 & - & 7 & 2 & 1 \\
\hline $\begin{array}{l}\text { Process terminated in the pre-trial } \\
\text { investigation stage }\end{array}$ & 12 & 3 & 11 & 15 & 5 & 6 & 14 \\
\hline $\begin{array}{l}\text { Percentage of processes terminated } \\
\text { because of acquittal, amnesty, expiry of } \\
\text { limitation period or reconciliation }\end{array}$ & $9 \%$ & $11 \%$ & $4 \%$ & $0 \%$ & $6 \%$ & $1 \%$ & $1 \%$ \\
\hline Percentage of processes terminated & $24 \%$ & $16 \%$ & $14 \%$ & $13 \%$ & $11 \%$ & $6 \%$ & $9 \%^{\mathrm{d}}$ \\
\hline
\end{tabular}

(Source Authors, on the basis of a variety of documents indicated in the footnotes in the Table) ${ }^{a}$ Data from the CEPS report noted in the Questionnaire

${ }^{\mathrm{b}}$ Data from the Annual reports of the Prosecution Service of the Republic of Lithuania at http:// www.prokuraturos.1t/Veikla/Veiklosataskaitos/tabid/515/Default.aspx

${ }^{\mathrm{c}}$ The Experts were unable to obtain exact data on acquittals

${ }^{\mathrm{d}}$ In 2012 this percentage was the lowest ever - 4\% (191 persons transferred; 8 cases of termination)

the activities of the state in the area of criminal justice. As it has already been mentioned, the ensuring of such costs is an obligation of the state, which may not be transferred to the person subject to prosecution. Thus, the extradition of R.E. to the Republic of Lithuania is one of the political functions to be financed by the state from its budget; hence, the extradition costs in this case may not be considered as procedural costs.

2.3.4.2 The statistics of the operation of the EAW in Lithuania are summarised in Table 1.

According to the data, there is an obvious trend indicating the increasing efficiency of EAWs year over year. The percentage of extradited persons who have been found innocent in the courts of first instance is approximately $1 \%$. This is not extraordinary compared to the data on general domestic trials. Annually, 1-2\% of all cases in the Lithuanian courts of first instance result in acquittal, as summarised in Table 2.

Compensation for individuals who have been extradited and subsequently found innocent could be provided on the grounds already provided for in the legislation of the Republic of Lithuania. Article 30 of the Constitution states that '[any] person whose constitutional rights or freedoms are violated shall have the right to appeal to [a] court. Compensation for material and moral damage inflicted upon a person shall be established by law'. These provisions are further elaborated in the Civil 
Table 2 Accused found innocent in the courts of first instance

\begin{tabular}{|c|c|c|c|}
\hline Data of the courts of first instance ${ }^{a}$ & 2010 & 2011 & 2012 \\
\hline Convicted & 17322 & 16342 & 17472 \\
\hline Acquitted & 227 & 294 & 405 \\
\hline Percentage & $1,3 \%$ & $1,8 \%$ & $2,0 \%$ \\
\hline
\end{tabular}

(Source National Courts Administration, and Reports of the Prosecution Office of the Republic of Lithuania (Data from the National Courts Administration: http://www.teismai.lt/lt/teismai/teismaistatistika/; and Reports of the Prosecution Office of the Republic of Lithuania. http://www. prokuraturos.lt/Veikla/Veiklosataskaitos/tabid/515/Default.aspx))

${ }^{a}$ It is worth noting that the data is very similar compared to the outcomes of cases in the Lithuanian courts of all instances. See http://osp.stat.gov.lt/services-portlet/publication-file/4224/24_ Nusikalstamumas_\%202012.pdf

Code (Art. 6.272) and the Law on Compensation for Damage Inflicted by Unlawful Actions of Government and on Representing the State (Art. 4). According to these laws, both pecuniary and non-pecuniary damage resulting from unlawful arrest, conviction or detention shall be compensated, with a maximum limit of 10,000 LTL (2,900 EUR) for pecuniary and 5,000 LTL (1,500 EUR) for non-pecuniary damage in non-judicial order.

It must be noted that no precedents have been highlighted in the Lithuanian media with regard to compensation for damage to persons surrendered under an EAW and later found innocent in court.

\subsubsection{The Right to Effective Judicial Protection: The Principle of Mutual Recognition in EU Criminal Law and Abolition of the Exequatur in Civil and Commercial Matters}

2.3.5.1-2.3.5.3 No constitutional issues similar to those indicated in the questionnaire have arisen in the constitutional jurisprudence, court practice or legal commentary of Lithuania with regard to mutual recognition in criminal law and the abolition of the exequatur in civil and commercial matters. ${ }^{76}$

Moreover, there have been no debates about the suitability of transposing mutual recognition from internal market matters to criminal and civil procedures either in the doctrine of criminal procedure or in the doctrine of civil procedure of Lithuania. No concerns have been expressed about a change in the role of the courts. In the opinion of Vytautas Nekrošius (a leading expert in the field of Lithuanian civil procedure), the abolition of the exequatur in civil and commercial matters has been accepted favourably in the doctrine of Lithuanian civil procedure.

2.3.5.4 The practical application of the EAW has revealed a serious problem with regard to issuing EAWs in Lithuania: until 2013 neither the prosecutors nor the

\footnotetext{
${ }^{76}$ Regarding the reasons, see Sect. 2.3.1.1.
} 
courts applied a proportionality test. ${ }^{77}$ During the fourth round of mutual evaluations, ${ }^{78}$ prosecutors expressed the following concern:

Under Article 2 of the CCP the prosecutor is obliged to prosecute all criminal acts and to take all steps and action under the law to prosecute an offender, domestically or otherwise. This provision was referred to by the Lithuanian authorities as the 'principle of legality'. In application of this principle no proportionality test whatsoever is applied in issuing EAWs, although Lithuanian authorities informed the expert team that in practice in certain cases in view of the resources used compared to the gravity of the criminal offence - they may choose not to issue an EAW in the first place but to exploit other possibilities to address the issue (such as MLA requests). This may explain, together with a rather strong criminal environment, why Lithuania issues around 500 EAWs per year. In per capita terms this is most probably the highest rate of issue of any Member State.

However, the situation changed significantly in 2013 after the adoption of amendments to Art. $69^{1}$ of the CCP, which provides: '[the] Lithuanian Prosecutor General's Office or the Regional Court, acting on a European arrest warrant ..., must evaluate whether the transfer of the person under the European Arrest Warrant is in line with proportionality and procedural economy, taking into account the nature and extent of the severity of the committed crime, as well as the personality of the suspect, accused or convicted person'. It should be emphasised that Lithuanian judges and prosecutors are of the opinion that control of the proportionality of EAWs is among the most important issues raised in recent years.

Moreover, the non-legally binding European Handbook on How to Issue a European Arrest Warrant, which provides guidance for improving the uniformity of the application of the EAW across the EU and includes the proportionality test amongst the factors to be examined by national authorities when issuing an EAW as well as alternatives to issuing an EAW, has also played a very important and positive role in this context.

\subsubsection{Constitutional Rights Regarding Other Aspects of EU Criminal Law}

Doubt has been expressed in the theory of Lithuanian criminal law with regard to the manner in which the EAWFD provisions were drafted, in particular whether they are in conformity with the requirements of Art. 13 of the Constitution, according to which a citizen of the Republic of Lithuania may be surrendered only in the cases specified in the international treaties concluded by Lithuania. Some authors (for example, Algimantas Čepas) claim that the EAWFD specifies that it has been adopted under para. 2(b) of Art. 34 TEU, whereby the EU Member States have delegated to the Council of the EU the power to adopt Framework Decisions, and that therefore, the grounds for surrendering Lithuanian citizens is the TEU as an

\footnotetext{
77 Švedas and Mickevičius 2009, p. 354; Žižienè 2014, pp. 450-452. For similar problems in other Member States, see Weyembergh et al. 2014.

${ }^{78}$ Report on Lithuania, supra n. 61, p. 32.
} 
international treaty. ${ }^{79}$ Similar arguments have also been upheld by the Court of Appeal, which has concluded in one of its rulings ${ }^{80}$ regarding the surrender of a Lithuanian citizen, M.M., to France under an EAW that 'the surrender of persons under the European Arrest Warrant is provided for in an international treaty of the Republic of Lithuania, which has supremacy in respect of the rules of Art. 226 of the Code of Criminal Procedure of the Republic of Lithuaniaa ${ }^{81}$

On the other hand, such arguments raise certain doubts, ${ }^{82}$ because in cases of extradition the court directly applies the provisions of the international treaty on extradition of the Republic of Lithuania, the $\mathrm{CC}$ and the $\mathrm{CCP},{ }^{83}$ whereas when deciding the issue of surrendering any person (including a citizen of the Republic of Lithuania) under an EAW, the court in fact applies only the provisions of the CC and the CCP. Nevertheless, the actual provisions of the CC and CCP continue to be applied as they stand and the aforementioned question of a constitutional nature can only be resolved by the $\mathrm{CC}$ if such a case is submitted to it.

\subsection{The EU Data Retention Directive}

2.4.1 Article 22 of the Constitution protects the right to privacy and secrecy of communications as follows:

The private life of a human being shall be inviolable. Personal correspondence, telephone conversations, telegraph messages, and other communications shall be inviolable. Information concerning the private life of a person may be collected only upon a justified court decision and only according to the law.

It may be worth noting that by using the term 'inviolable', the provision is stricter than the equivalent provisions in the EU Charter and the ECHR that refer to 'respect' for private and family life, home and communications (Art. 7 of the Charter).

\footnotetext{
79 Švedas 2004, p. 75.

${ }^{80}$ Criminal case No. $1 \mathrm{~N}-11 / 2006$.

${ }^{81}$ Čepas and Švedas, pp. 84-85. Translation by the author.

82 Švedas 2008, p. 66; Švedas 2010, pp. 946-947.

${ }^{83}$ It should be noted that this practice of the courts has been held to be well-founded by the Supreme Court of Lithuania in para. 2 of the Senate's Ruling No. 42 'On the practice of courts in applying international treaties of the Republic of Lithuania and the provisions of the Criminal Code and the Code of Criminal Procedure, regulating the surrender of persons to foreign States or to the International Criminal Court' of 29 December 2003, where it emphasised that in 'deciding whether there are grounds and conditions to surrender the person to a foreign state ..., the Vilnius County Court shall follow international treaties, Art. 9 of the Criminal Code and Art. 71 of the Code of Criminal Procedure' (translation by the author).
} 
The adoption and implementation of the Data Retention Directive ${ }^{84}$ in Lithuania has not raised any wide constitutional concerns neither in court practice nor at the political level. However, some commentators, including the author of the present report, supporting the views of the Art. 29 Data Protection Working Party established under Directive 95/46, ${ }^{85}$ have voiced doubts as regards the compatibility of the then draft data retention framework decision, which later became the Data Retention Directive, both conceptually (that is, the regime itself: data retention versus data preservation) and regarding certain details (the scope of collectable data; the length of the retention period, the lack of judicial control, etc.). ${ }^{86}$ These doubts were based both on the jurisprudence of the European Court of Human Rights (ECtHR) ${ }^{87}$ and of the CC.

The CC ruled in 2002 that the right to the inviolability of private life is not absolute. Under the Constitution, restriction of the constitutional rights and freedoms of the individual is permitted if certain conditions are observed (see Sect. 2.1.2). ${ }^{88}$ The Court ruled that Art. 22 requires, inter alia, that the legislature establish by a law a procedure for collection of information about the private life of an individual. While the law must provide that information concerning the private life of an individual may be collected upon a reasoned court decision only, ${ }^{89}$ the Court pointed out that the obligation on the part of operators to collect, store and provide all communications data to state institutions at their own expense is contrary to Arts. 22 and 23 of the Constitution (protection of the right to privacy and property).

The Directive was implemented by amendments to the Electronic Communications Law (Art. 65 and Annex I) by restating the relevant contents of the Directive and adding that the operators have to provide data to state institutions for free. Because of this, all of the constitutional concerns raised by the ECJ in the Digital Rights Ireland judgment as well as by the constitutional courts of some of the Member States in their respective decisions are also relevant for Lithuania. It could be said that the relevant provisions of the Law are clearly excessive and disproportionate and have failed to establish proper mechanisms for supervision, including judicial control. Additionally, they go against the ruling of the $\mathrm{CC}$ as regards the provision of data to state institutions for free. Therefore, the annulment

\footnotetext{
${ }^{84}$ Directive 2006/24/EC of the European Parliament and of the Council of 15 March 2006 on the retention of data generated or processed in connection with the provision of publicly available electronic communications services or of public communications networks and amending Directive 2002/58/EC, [2006] OJ L 105/54.

${ }^{85}$ See Opinion 4/2005 of the Art. 29 Data Protection Working Party. http://ec.europa.eu/justice/ policies/privacy/docs/wpdocs/2005/wp113_en.pdf.

${ }^{86}$ Jarukaitis et al. 2005, pp. 369-375; Štitilis 2006, pp. 69-75.

${ }^{87}$ For example, Amann v. Switzerland [GC], no. 27798/95, ECHR 2000-II.

${ }^{88}$ Ruling of 23 October 2002.

${ }^{89}$ Ruling of 19 September 2002.
} 
of the Data Retention Directive should trigger at least a review of the Electronic Communications Law, although hitherto no formal amendments have been tabled before the Parliament.

\subsection{Unpublished or Secret Legislation}

2.5.1 Article 7(2) of the Constitution explicitly stipulates that only laws which are promulgated shall be valid. The CC treats this requirement as part of the principle of the rule of law. In its rulings of 11 January 2001 and 29 November 2001, the Court made it clear that law must not be secret; laws are not valid and must not be applied until they are officially published. It stressed that an essential element of the principle of the rule of law is that only published legal acts are effective; the constitutional requirement that legal acts must be published to have legal effect is an important precondition of legal certainty. Indeed the $\mathrm{CC}$ went so far as to state that all acts of the Government (of normative or individual nature) must be published; the Court annulled a provision of a law which provided that resolutions of the Government 'in which legal norms are not established, amended or acknowledged as no longer valid' need not be published as well as the contested decision of the Government that had not been officially published, as contrary to the principle of the rule of law.

The SAC has developed similar practice. Where it has faced the question of conformity of normative acts (e.g. municipality regulations, ministerial orders, etc.) to the laws or decrees of the Government and a review of legality of a certain act has been initiated, the court, after establishing that the contested act has not been properly published, has refused to initiate the case, stating that it does not have the competence to review the legality of non-existent acts (that is, the content of the act does not exist, since it was not published). ${ }^{90}$

The SAC has also had to deal with the legality of individual acts that have been adopted on the basis of (not properly published) unpublished EU legislation. After clarifying with the Office of Publications that the relevant EU regulation had been properly published in Lithuanian only after the adoption of the contested administrative act issued by the customs authority by which an additional customs duty and a pecuniary fine were imposed on a company, the Court, relying on the ECJ Skoma-Lux judgment, annulled the contested measure. ${ }^{91}$

\footnotetext{
${ }^{90}$ For example, Ruling of 3 May 2012 in Case No. $\mathrm{I}^{492}-30 / 2012$.

${ }^{91}$ Decision of 25 July 2011 in Case No. $A^{438}-305 / 2011$.
} 


\subsection{Rights and General Principles of Law in the Context of Market Regulation}

2.6.1 No direct constitutional or similar challenges have been brought before the national courts concerning the national implementing measures for the EU transitional measures concerning agricultural stocks.

However, the Lithuanian Government was successful in challenging a Decision of the Commission concerning the obligation of the state to remove from the market all agricultural stocks which could not be considered as normal carryover stocks. Although it took the General Court five years to deliver the judgment, it annulled Commission Decision No. 2007/361/EC in 2012. ${ }^{92}$

The practice of the $\mathrm{CC}$ reveals its readiness to annul market regulation measures on the basis of a violation of the prohibition of retroactive effect of legal acts, ${ }^{93}$ or of the principles of proportionality, ${ }^{94}$ legal certainty ${ }^{95}$ or legitimate expectations, ${ }^{96}$ although the principle of legitimate expectations has entered the CC's 'vocabulary' rather late, in response to legislative practice in the field of social issues, which itself was a reaction to the economic crisis of $1998-1999 .{ }^{97}$ It can also be said that the Court in its jurisprudence uses more ECtHR than ECJ case law as a source of inspiration.

\subsection{The ESM Treaty, Austerity Programmes and the Democratic, Rule-of-Law-Based State}

2.7.1-2.7.3 The ratification of the Treaty Establishing the European Stability Mechanism (ESM Treaty) has mostly been discussed in Lithuania in the context of the introduction of the euro as of 1 January 2015. In order to introduce the euro, Lithuania had to join the ESM Treaty, which was done by a parliamentary law adopted on 18 December 2014. The explanatory memorandum that was submitted to Parliament with the draft ratification law treated the ratification of the ESM

\footnotetext{
92 Case T-262/07 Republic of Lithuania v. European Commission [2012] ECLI:EU:T:2012:171. The Court ruled that the Commission used the wrong methodology and was not able to show that the exports of surplus stocks actually took place or that other measures for eliminating the surpluses were taken, or that they were financed by the Community budget, i.e. it ruled that the Commission overstepped its wide discretion and violated provisions of the Act of Accession. From the point of view of this project, it may be worth noting that the Lithuanian Government's arguments were not formulated in constitutionalist terms.

${ }^{93}$ Ruling of 29 November 2001.

${ }^{94}$ Ruling of 14 March 2002.

${ }^{95}$ For example, Rulings of 17 March 2003; 31 May 2006.

${ }^{96}$ Rulings of 23 February 2000; 13 May 2005; 5 July 2007.

97 Šileikis 2005, p. 254.
} 
Treaty as an additional financial guarantee for the state financial system. There were some discussions both within the Parliament and in the general public concerning the far-reaching obligations undertaken under the ESM Treaty, but these discussions were to some extent overshadowed by events in Ukraine, since accession to the eurozone is viewed in Lithuania not only from the economic but also from the geopolitical perspective.

It should further be noted, that the SAC has had to deal with a case concerning the lawfulness of the refusal of the Central Electoral Commission to register an application from a referendum initiative group concerning amendment of the Constitution with regard to the (non)introduction of the euro in 2014. Similarly as in the case before the Polish Constitutional Tribunal, the extensive financial obligations under the ESM Treaty were mentioned as one of the secondary arguments, with the claim that the obligation to introduce the euro under the Accession Treaty had in fact been annulled since the conditions of participation had changed dramatically. ${ }^{98}$

The different (constitutional) aspects of the ESM Treaty, Eurobonds and the Banking Union have not attracted the attention of Lithuanian legal scholars so far. In the Expert's opinion, as regards commitments under the ESM Treaty, two main, interrelated issues arise. The first concerns the intensity of solidarity desired at the EU level, since financial resources pooled under the ESM Treaty would be used for those in need (therefore Member States do not only undertake financial commitments, but they also receive guarantees). The second concerns democracy at the national level, since commitments under the ESM reduce the ability of the national parliaments to decide on spending.

The financial crisis is considered further below in Sect. 3.5.

\subsection{Judicial Review of EU Measures: Access to Justice and the Standard of Review}

2.8.1 There are no statistics on the number of cases in which the applicants have requested a preliminary ruling regarding the validity of an EU legal measure in the Lithuanian courts. However, given the fact that applicants in Lithuania are still rather reluctant to rely on EU law, it may be assumed that the number of such requests is very low. In the majority of requests for a preliminary ruling to the ECJ, Lithuanian courts have raised questions regarding the interpretation and not the validity of EU acts. So far there has only been one request from the Vilnius District Administrative Court concerning the validity of various provisions of Regulation No. 73/2009/EU and the Commission Implementing Decision C (2012) 4391,

\footnotetext{
${ }^{98}$ See the Ruling of the SAC of 18 July 2014 in Case No. R-858-11-14. The Court rejected this argument and stated that the ESM Treaty may not be viewed as a factor modifying the obligations undertaken under the Accession Treaty without its formal amendment.
} 
which was submitted to the ECJ on 4 March 2014 (Jakutis and Kretingales kooperatine $\check{Z} \bar{U} B$, C-103/14). ${ }^{99}$

2.8.2-2.8.5 Looking at the latest ECJ case law that has been developed after the entry into force of the Charter of Fundamental Rights and the methodological approach of the Court in these cases, ${ }^{100}$ it is difficult to draw the definite conclusion that the ECJ standard of judicial review is clearly lower than that performed by the Lithuanian courts. Admittedly, the Sugar quotas case law raises certain questions as regards the intensity of judicial review; however, in the Expert's view, this may to some extent be explained by the transitional (one-off) nature of the contested measures. On the other hand, the $\mathrm{CC}$ has also exhibited certain self-restraint in the evaluation of measures which involve complex policy choices.

The CC jurisprudence reveals different approaches in terms of the intensity of judicial review depending on the content of the contested legal provisions. Where the $\mathrm{CC}$ has been faced with questions related to ex ante economic (or other) policy formation or implementation, it has demonstrated judicial self-restraint: the CC has emphasised the wide discretion of political institutions, which means that from the point of view of the principle of proportionality, the Court has used the test of manifest error, instead of rigorous scrutiny. Still, the Court has been certain to check whether the contested provisions are in line with the general principles of law. ${ }^{101}$ This approach is similar to that of the ECJ when it is called upon to evaluate decisions involving political, economic and social choices. ${ }^{102}$

\footnotetext{
${ }^{99}$ The request related to the question of differences in direct payments to farmers of the 'old' and 'new' Member States and the conformity of various provisions of Regulation No. 73/2009 establishing common rules for direct support schemes for farmers under the common agricultural policy and the Commission Implementing Decision C(2012) 4391 final with the Accession Treaty and the general principles of EU law. The ECJ in its judgment of 12 November 2015 found no grounds affecting the validity of Regulation No.73/2009, but declared the Commission Implementing Decision C(2012) 4391 of 2 July 2012 contrary to the 2003 Act of Accession. The Implementing Decision ordered, inter alia, the reduction of complementary national direct payments paid to Lithuanian farmers in 2012 if certain levels of direct payments were surpassed.

${ }^{100}$ For example, see Joined cases C-92/09 and C-93/09 Volker und Markus Schecke and Eifert [2010] ECR I-11063; Case C-236/09 Association Belge des Consommateurs Test-Achats and Others [2011] ECR I-00773; C-283/11 Sky Österreich ECLI:EU:C:2013:28; and Joined cases C-293/12 and C-594/12 Digital Rights Ireland and Seitlinger and Others [2014] ECLI:EU: C:2014:238.

${ }^{101}$ For example, in its Ruling of 31 May 2006, the Court found: 'Under the Constitution, the Seimas as the institution of legislative power and the Government as an institution of executive power enjoy very broad discretion to form and execute the economic policy of the state (each according to their competence) and to properly regulate economic activities by means of legal acts, by not violating the Constitution and laws, inter alia by not exceeding the powers established in them to the said institutions of state power and by following the requirements of the proper legal process which stems from the Constitution and the principles of a state under the rule of law, of separation of powers, of responsible governance, of protection of legitimate expectations and the principles of legal clarity, certainty and security' (translation by the author; emphasis added).

${ }^{102}$ For example, Case C-289/97 Eridania [2000] ECR I-05409; Case C-127/07 Arcelor Atlantique and Lorraine and Others [2008] ECR I-09895.
} 
In other cases, where the contested measures have been more an ex post reaction to various market failures (e.g. the establishment of exclusive rights in areas where a natural monopoly exists) or where the balancing of the freedom of business activities with other (societal) non-economic ends is involved, judicial review has been more intensive. ${ }^{103}$ The $\mathrm{CC}$ has invalided national provisions on various grounds: breach of the principle of non-discrimination and the grant of unlawful privileges, ${ }^{104}$ non-respect of legitimate expectations and excessive restrictions on economic activities, ${ }^{105}$ breach of proportionality ${ }^{106}$ and the rights of consumers. ${ }^{107}$

Thus, as a matter of the test applicable, it is not possible to say that the judicial review performed by the CC and the judicial review by the ECJ are conceptually different. Of course, when it comes to the evaluation of a particular situation, views may differ.

As regards the judicial review of EU legal acts or national acts implementing EU law at national level, Lithuanian commentators agree that judicial review of EU legal acts is not possible before the $\mathrm{CC}^{108}$ or the SAC. The CC has never elaborated on this issue and de facto has never performed such control. In the Expert's opinion, such control is not possible due to the fact that the Constitution clearly defines the legal acts which may be subjected to constitutional control before the $\mathrm{CC}$; these, according to Art. 105, are laws of the Republic of Lithuania, other acts adopted by the Seimas, and acts of the President and of the Government. There is no right of an individual constitutional complaint before the $\mathrm{CC}$ in Lithuania.

The $\mathrm{CC}$ in its practice has never differentiated between national acts depending on whether they implement EU law or not (again, there is no legal basis to do so). To date, when reviewing the constitutionality of national laws that implement EU law, the CC has taken 'the EU law dimension' into account by either referring questions for a preliminary ruling to the ECJ (see Sect. 1.3.4 above) or referring to EU law itself when interpreting the relevant provisions of the Constitution. After the Ruling of 24 January 2014, it appeared theoretically possible that the CC could rule that a national provision implementing EU law contravenes the Constitution, if the innate nature of human rights and freedoms would be negated. It could be argued that the principle of loyal co-operation would require that the $\mathrm{CC}$ address the ECJ first with regard to a challenge to the validity of the relevant EU provision.

\footnotetext{
${ }^{103}$ For example, in its Ruling of 26 January 2004 the Court noted that rights and freedoms, as well as the freedom of economic activity may be restricted on the conditions noted earlier in the report, and proceeded to note that ' $[\mathrm{t}]$ he state and its institutions, having the discretion to establish the special legal regulation of alcohol production and the market, may not do so by choosing means so inadequate to the objectives sought, by which they would introduce the monopoly of production and the market of these products, [and] would groundlessly restrict the freedom of economic activity and fair competition' (translation by the author).

${ }^{104}$ Rulings of 20 April 1995; 17 March 2003; 26 January 2004.

${ }^{105}$ Ruling of 23 February 2000.

106 Ruling of 14 March 2002.

${ }^{107}$ Rulings of 17 March 2003; 20 September 2010.

108 Jarašiūnas 2004, p. 26; Namavičius 2004, p. 135; Kūris 2004a, pp. 199-200; Abramavičius 2006, p. 313; Jarukaitis 2010a, pp. 256-257.
} 
2.8.6 So far there has been no judicial practice related to the question of equal treatment of persons depending on whether they fall within the scope of EU law or not. This might be because of the fact that as a rule, there would be no differentiation from the point of view of the Constitution or Lithuanian laws; the main dividing line is between persons having Lithuanian or EU citizenship and third country nationals.

\subsection{Other Constitutional Rights and Principles}

2.9.1 According to the $\mathrm{CC}$, restrictions of fundamental rights and freedoms may be imposed only by laws adopted by Parliament. Further, the $\mathrm{CC}$ has explicitly stated in 2002 that the Constitution does not allow for the delegation of legislative powers from the Parliament to the Government. ${ }^{109}$ Thus, Art. 1 of the CA is the only explicit exception to this prohibition in the sense that it legitimates the transfer of legislative powers to the Council and in doing so implicitly acknowledges that the ministers act as legislators in the Council. Such approach has not changed after Lithuania's accession to the EU. The only change has been the introduction of the fast-track procedure for the adoption of EU related draft law in the Statute of the Parliament, which aims to ensure the timely implementation of EU law.

\subsection{Common Constitutional Traditions}

2.10.1-2.10.2 In the Expert's opinion, the ECHR is the best reflection of the common minimum standard of protection of fundamental rights and freedoms within the Member States. Therefore, all the rights and general principles of law addressed in the Questionnaire may be treated as part of the common constitutional traditions.

With regard to promotion of the relevance of national constitutional traditions on the EU level, several aspects should be noted. National constitutional imperatives are of particular importance in the EU legislative process. In the Expert's view, these imperatives are addressed to all national institutions, including national governments which vote within the Council. It means, inter alia, that the national minister has the obligation to vote against a draft EU measure, which would, once adopted, create a conflict between the national constitution and EU law (except in situations where there are plans to modify the relevant constitutional provision).

${ }^{109}$ Ruling of 26 October 1995. 
When interpreting and applying EU law, national courts refer to national constitutional provisions in their requests for preliminary rulings from time to time. ${ }^{110}$ Arguments related to national constitutional traditions submitted by the courts in references for preliminary rulings are welcome and should be promoted as an important tool for maintaining the relevance of national constitutional traditions in the discourse on human rights at the EU level.

As regards reflection of national constitutional traditions in ECJ judgments, several aspects should be noted. Bearing in mind the current number of Member States, it would be impossible to reflect on all of the relevant constitutional traditions in each judgment of the ECJ. If this is not possible, the question rises as to the methodology the ECJ should choose to identify which Member States' traditions would be considered, and the ECJ may be subjected to criticism on this point. ${ }^{111}$ Further, extensive references to national legal traditions would usually relate to the interpretation of national law. It should also be noted that such comparative reflection should not be seen as an end in itself, but as a tool for finding optimal solutions to problems raised. Thus, in the Expert's opinion, the most appropriate tool for extensive reflections on national constitutional traditions are the opinions of the Advocates General.

Nevertheless there is one particular area which inevitably calls for a deeper analysis of national constitutional traditions and where direct references to national constitutional traditions are not only welcome, but necessary. These are cases where the Member States rely on Art. 4(2) of the TEU. Given the fact that the obligation to respect the national constitutional identities of the Member States extends to all EU institutions, including the ECJ, the Court has the obligation to respond to such arguments and to balance the imperative of EU law to respect national identity against other imperatives of EU law. ${ }^{12}$

\footnotetext{
${ }^{110}$ See, for example, Case C-314/13 Peftiev and Others [2014] ECLI:EU:C:2014:1645, which concerned the possible unfreezing of assets by a national institution that were needed for legal representation before the General Court. In the reference to the ECJ, the SAC noted that a literal interpretation of the relevant provisions of Regulation No. 765/2006 of 18 May 2006 concerning restrictive measures in respect of Belarus would not be compatible with the right to judicial defence, as guaranteed by Art. 47 of the Charter of Fundamental Rights, Art. 6 of the ECHR and Art. 30 of the Constitution of Lithuania. In its judgment the ECJ, although without mentioning the Constitution of Lithuania explicitly, broadly adopted the approach proposed by the SAC.

${ }^{111}$ The Expert has no doubt that 'internally' the ECJ undertakes such analysis of national constitutional traditions, however; this should not always be reflected in the text of the judgment.

${ }^{112}$ For example, Case C-391/09 Runevič-Vardyn and Wardyn [2011] ECR I-03787.
} 


\subsection{Article 53 of the Charter and the Issue of Stricter Constitutional Standards}

2.11.1 With regard to higher or lower standards for human rights protection, one has to bear in mind what rights are involved. Commentators writing on the Melloni judgment have usually tended to emphasise the right of the suspected/accused/ convicted person to a public hearing (which in fact the person in the main proceedings decided to waive). However, what about the rights of the victims of the crime (this question is of relevance especially taking into account the facts in the main proceedings, where the whole story began already in 1996!)? Should victims of crime be afforded lower standards of protection simply because of the fact that the suspected/accused/convicted person used his/her right of free movement under EU law, or should there be a balance between the two?

In the Expert's opinion, the ECJ judgment in Melloni is quite balanced, since the main emphasis was placed on the compatibility of the Framework Decision with the Charter and the responsibilities of the Member States: if they do not want to have a single set of rules, the requirement of unanimity in the Council ensures the right of the Member State to maintain a higher standard of protection. Thus, if there is no 'EU consensus' in the form of a piece of secondary EU law, Art. 53 remains relevant. Otherwise, in terms of legal logic it is quite difficult to come to some other conclusion than the ECJ: how could provisions of the Framework Decision, which were declared to be compatible with the Charter, not be applicable to the Member State which agreed to be bound by it, unless the Member State has claimed that it contravenes Art. 4(2) TEU, which was not the case $?^{113}$ Moreover, the Charter itself does not oblige the Member States to provide for a higher standard in every situation. If the Framework Decision left discretion to the Member States to adopt a different ('higher') standard, what would be the purpose of adopting the Framework Decision?

\subsection{Democratic Debate on Constitutional Rights and Values}

2.12.1 There have been no wide public deliberations either at the time of adoption or at the time of implementation of the EAW Framework Decision and the EU Data Retention Directive in Lithuania.

2.12.2-2.12.3 Normally, democratic deliberations should take place before an EU measure is adopted. If the Member States envisage that an EU measure might trigger possible constitutional reforms or involve difficult value choices at the national level, they should take this into account by establishing a longer

${ }^{113}$ See Case C-399/11 Melloni [2013] ECLI:EU:C:2013:107, paras. 62-63. 
transposition period. As regards the national constitutional review of national implementing measures, the question is whether the constitutional issue is predetermined by the EU measure itself. If the answer is positive, there are no obstacles to using the preliminary ruling procedure in order to check the validity of the EU measure and to ask for the application of interim measures under Art. 279 of the TFEU. Thus, one has to differentiate between situations where the unconstitutionality of a national measure is predetermined by the unconstitutionality of the EU measure itself, and situations that concern purely 'internal'/national unconstitutionality issues.

As for the permissibility of an 'unconstitutionality' defence in the course of infringement proceedings, this would be highly problematic from the point of view of the equality of the Member States and EU citizens. The only approximate legal basis for such a defence would be Art. 4(2) of the TEU with the argument that the EU measure violates the obligation to respect the national identity of the Member State; however, it would be difficult to explain why the Member State did not use the annulment procedure in order to contest the EU measure if it clearly violates the core values of the particular Member State. It would be also difficult to introduce any element of subjectivity in infringement proceedings, since this would open the door for other 'innocent' excuses (like failure to form a Government or to achieve the necessary majority in the national parliament, etc.).

\subsection{Experts' Analysis on the Protection of Constitutional Rights in EU Law}

2.13.1-2.13.2 The Expert is of the opinion that there is no basis to speak of the overall reduction of the standard of protection of fundamental rights or the rule of law which is predetermined by EU law. One of the exceptions to this general conclusion is the field of criminal law or, to be more precise, the abandonment of the double criminality rule for some categories of offences in the EAW Framework Decision. In other fields, in the majority of cases the problems lie at the level of implementation/application of EU law or in the national implementing measures. Moreover, the entry into force of the Charter of Fundamental Rights has been of utmost importance for providing the ECJ with an important tool to tackle problems related to the protection of fundamental rights.

In the Expert's view, one of the most important things to do is to ensure true democratic deliberations before the adoption of an EU measure. To do so, national parliaments, NGOs and the academic community should all play a role.

Given the complexity of EU decision-making and the process of implementing EU law, ex-ante constitutional review of draft EU measures before the ECJ could be considered as an option to ensure the timely evaluation of possible constitutional concerns. 
Finally, it seems that national (constitutional) courts have become more active in recent years in using the preliminary ruling procedure, which is a welcome development.

2.13.3-2.13.4 So far, Lithuanian courts have not raised any constitutional concerns before the ECJ. The question of national constitutional concerns is quite delicate, since in some cases (e.g. the EAW Framework Decision as regards the surrender of nationals) the adoption of the EU measures may explicitly or implicitly pre-suppose national constitutional reforms, and failure to implement such constitutional revisions could hardly be treated as a legitimate excuse for failure to implement EU law. On the other hand, if a Member State bases its defence on the national identity clause (Art. 4(2) of the TEU), the ECJ has the obligation to respond to this argument properly, as required by Art. 6 of the ECHR and the jurisprudence of the ECtHR.

\section{Constitutional Issues in Global Governance}

\subsection{Constitutional Rules on International Organisations and the Ratification of Treaties}

3.1.1-3.1.4 Article 136 of the Constitution provides that ' $[t]$ he Republic of Lithuania shall participate in international organizations provided that this is not in conflict with the interests and independence of the State'. Additionally, Art. 135(1) of the Constitution states that '[i]n implementing its foreign policy, the Republic of Lithuania shall follow the universally recognized principles and norms of international law, shall seek to ensure national security and independence, the welfare of the citizens and their basic rights and freedoms, and shall contribute to the creation of the international order based on law and justice'.

These constitutional provisions were established in the original version of the Constitution, adopted in 1992, and are treated as the constitutional basis for Lithuania's participation in international organizations other than the EU, for which the separate Constitutional Act was adopted. No formal amendments of Art. 135 or 136 have been tabled before the Parliament so far.

In 2011, the CC ruled implicitly that Art. 136 is the proper constitutional basis for Lithuania's participation in NATO. ${ }^{114}$

In the Expert's opinion, the current constitutional provisions are adequate and no amendments are needed.

${ }^{114}$ Ruling of 15 March 2011 


\subsection{The Position of International Law in National Law}

3.2.1-3.2.2 Under Art. 138(3) of the Constitution, international treaties ratified by the Seimas shall be a constituent part of the legal system of the Republic of Lithuania.

According to the jurisprudence of the $\mathrm{CC}$, treaties that have been ratified by the Parliament have the force of law and may be directly applied in Lithuania. In the case of a conflict between a ratified treaty and a statute adopted by the Parliament (let alone lower sources of law such as governmental decrees, etc.), provisions of the treaty have priority. However, this rule is clearly not applicable to the Constitution itself, which has precedence over ratified treaties. ${ }^{115}$

In the legal commentary, the approach of the $\mathrm{CC}$ to international treaties is treated as monistic, ${ }^{116}$ since the provisions of treaties may directly generate rights for private persons at the national level. The ECHR has received special treatment, as the CC has explicitly acknowledged the impact of the ECHR on the Lithuanian legal system, including on the Constitution of Lithuania. ${ }^{117}$ It is also the source of international law that is most frequently applied by the Lithuanian courts. ${ }^{118}$

Of course, the process of globalisation has modified the interrelationship between the national and international levels of governance in various ways. Still, the concepts of monism and dualism remain relevant to the extent that they explain whether, as a matter of principle, provisions of international law are a source of law from the point of view of the national constitution, that is, whether private persons may defend their rights directly on the basis of international law in the national courts.

\subsection{Democratic control}

3.3.1-3.3.2 Article 67(16) of the Constitution envisages that the Parliament shall ratify and denounce international treaties and consider other issues of foreign policy. Article 138(1) lists the categories of international treaties which require ratification by the Parliament. These include treaties on the participation of the Republic of Lithuania in universal international organisations and regional international organisations; multilateral or long-term economic treaties; treaties regarding alteration of the state boundaries, defence of the state, peace treaties and treaties on the use of force; political co-operation with foreign states; mutual

\footnotetext{
${ }^{115}$ See, for example, Ruling of 5 September 2012 of the CC; Judgment of 6 March 2014 of the SAC in Case No. R525-8/2014.

116 Vadapalas 1998, pp. 47-48 and 55-62; Vadapalas and Jarukaitis 2003, pp. 473-478; Jarukaitis 2006a, pp. 385-390.

${ }_{117}$ Rulings of 8 May 2000; 29 December 2004; 15 November 2013; Kūris 2004b, p. 85-86.

118 Jarukaitis 2010b, pp. 176-195.
} 
assistance treaties; and treaties on the presence and status of Lithuania's armed forces on the territories of foreign states. Laws as well as international treaties may also provide for other cases in which the Seimas must ratify an international treaty.

The Law on International Treaties, adopted by the Parliament in 1999, regulates the procedures for the conclusion of international treaties in detail. It establishes a traditional approach to the conclusion and execution of international treaties, where the right of initiative belongs to the executive branch and, once negotiated, treaties are submitted to the Parliament for ratification. The executive branch is also responsible for the implementation of concluded international treaties at the national level. Neither the Constitution nor parliamentary statutes establish specific provisions concerning the ex post involvement of the Parliament in the supervision of the execution of international commitments. Under the Statute of the Seimas, the committees of the Parliament may discuss any questions, including those related to international issues or commitments. In practice, the Parliament and its committees discuss international issues on a regular basis.

With the exception of Lithuania's accession to the EU, no referendums have hitherto been held as regards participation in international organisations or the conclusion of any particular international treaty. There are no legal obstacles to organising a referendum on international matters.

\subsection{Judicial Review}

3.4.1 Article 105 of the Constitution grants the $\mathrm{CC}$ the powers of ex ante review (by adopting an opinion) of international treaties as regards their compliance with the Constitution. These powers have been used once, when Lithuania decided to ratify the ECHR. ${ }^{119}$ There have so far been no instances of ex post constitutional control of an international treaty ratified by Lithuania with regard to compliance with the Constitution.

As already noted in Part I, the CC treats the pacta sunt servanda principle as part of the constitutional principle of the rule of law. Indeed, the $\mathrm{CC}$ has gone so far as to say that no constitutional amendments that fail to comply with international obligations undertaken by Lithuania may be adopted. However, the recent ruling of the $\mathrm{CC}$ which declares that pursuant to the Constitution, the innate nature of human rights and freedoms may not be negated, may theoretically be treated as a possible ground for challenging international commitments that contravene this requirement.

${ }^{119}$ Opinion of 24 January 1995. 


\subsection{The Social Welfare Dimension of the Constitution}

3.5.1-3.5.2 The Constitution of Lithuania does not establish the principle of a social state explicitly. Nevertheless, both the $\mathrm{CC}^{120}$ and Lithuanian commentators ${ }^{121}$ tend to speak about the principle of social solidarity and the social orientation of the Constitution.

Lithuania was hit by the economic crisis of 2008-2009 particularly badly, the reason being the global recession and the price bubble in the real estate sector. The cuts in the public sector (salaries in the public service, pensions and social allowances) were drastic. Nevertheless, the Government decided to borrow from markets rather than from the IMF or other international institutions. One of the explanations for this decision was the argument that the conditions imposed by the IMF would reduce the ability of the Government to implement its own policies. Moreover, the probability of devaluation of the national currency also played its part. ${ }^{122}$ This decision of the Government received much criticism, because the interest rates in the international markets were much higher than those proposed by the IMF. ${ }^{123}$ Later, the CC ruled that certain measures introduced during the crisis that reduced social benefits and pensions were unconstitutional. ${ }^{124}$ Lithuania has not been subject to any EU or international bailout or austerity programme so far.

The constitutional discourse on this subject has not been developed in Lithuania. In the Expert's view, the social dimension of the Constitution first and foremost depends on the sound macro-economic policies of the state and its ability to compete on the European and global markets. The CC, relying on the principle of good governance, requires that all draft measures, the implementation of which would require extra state funding not envisaged in the budget adopted by the Parliament, should clearly indicate the source of necessary funding. ${ }^{125}$ Further, relying on Art. 128 of the Constitution, according to which '[d]ecisions concerning

\footnotetext{
${ }^{120}$ For example, Ruling of 1 July 2013.

${ }^{121}$ Kūris 2001, pp. 266-270; Šileikis 2005, pp. 210-214.

${ }^{122}$ For more details on the subject, see, for example, http://www.networkideas.org/featart/ apr2013/pdf/Kattel_Raudla.pdf; https://euobserver.com/opinion/114419.

${ }^{123}$ It should also be noted that the sharp decline in 2009-2011 was followed by a very brisk economic recovery during the last couple of years. According to the statistics, the Lithuanian economy exhibits one of the highest growth rates in the EU.

${ }^{124}$ For example, in the Ruling of 6 February 2012 the CC ruled, inter alia, that the reduction of social pensions for working persons contravenes Art. 48(1) of the Constitution, as '[e]ach human being may freely choose a job or business'; in the Ruling of 5 March 2013, the CC ruled that certain aspects of the reduction of maternity allowances were not in line with the principle of the rule of law (were not proportionate); in the Ruling of 1 July 2013, the CC ruled that the uneven reduction of the salaries of state officials, where the salary reductions of highly paid state officials were greater in comparison to those of persons who earned less, was not in line with Art. 29(1): 'All persons shall be equal before the law', Art. 48(1) 'Each human being ... shall have the right ... to receive fair pay for work' and the principle of the rule of law (proportionality principle).

${ }^{125}$ For example, Ruling of 13 December 2004.
} 
[State loans] and other basic property liabilities of the State shall be adopted by the Seimas on the proposal of the Government', the CC implicitly expanded the principle of democracy to the extent that all decisions related to 'basic property liabilities', i.e. having significant financial implications on the state budget, have to be approved by the Parliament. ${ }^{126}$

\subsection{Conclusions}

To conclude the Report, concerns related to the state of protection of fundamental rights or constitutionalism in general reveal the close interaction of the supranational and national levels. In the view of both Experts, there is no basis to speak of the overall decline in the standards of protection of fundamental rights or the rule of law which is predetermined by EU law. On the other hand, at least as regards Lithuania, analysis shows a lack of real discussion among the public concerning various issues decided at the EU level, which later have had a profound impact upon implementation at the national level (the adoption and implementation of the Data Retention Directive is one such example). Thus, there is a real need to stimulate both academic/analytic and public discussions about what is going on at the EU level. This would help to clarify national priorities and ensure the consistency of the actions of national institutions at the national and EU levels.

\section{References}

Abramavičius A. (2006) Narystė Europos Sajungoje ir Lietuvos Respublikos Konstitucinio Teismo igaliojimai (Membership in the European Union and the powers of the Constitutional Court of the Republic of Lithuania). Konstitucine jurisprudencija: 311-316.

Albi A. (2001) The Central and Eastern European Constitutional Amendment Process in Light of the Post-Maastricht Conceptual Discourse: Estonia and the Baltic States. EPL 7:433-454.

Besson S. (2004) Sovereignty in Conflict. European Integration Online Papers 8:15.

Čepas A., Švedas G. (2008) Tarptautinè teisinè pagalba baudžiamosiose bylose. Asmenų, įtariamų padarius nusikalstamą veiką, išdavimas baudžiamajam persekiojimui (ekstradicija, perdavimas Tarptautiniam baudžiamajam teismui arba pagal Europos arešto orderị). (International legal assistance in criminal cases. Surrender of suspected persons for criminal prosecution (Extradition, European Arrest Warrant, surrender to the International Criminal Court). Teisinès informacijos centras, Vilnius.

Goda G. (ed.) (2003) Lietuvos Respublikos baudžiamojo proceso kodekso komentaras (1220 straipsniai) (Commentary of the Code of Criminal Procedure of the Republic of Lithuania (Articles 1-220). Teisinès informacijos centras, Vilnius.

${ }^{126}$ For example, Ruling of 18 October 2000. 
Goda G., Kazlauskas M., Kuconis P. (2011) Baudžiamojo proceso teisè (Law of criminal procedure). Registrų centras, Vilnius.

Jarašiūnas E. (2001) Konstitucijos teorijos pagrindai (The foundations of constitutional theory). In: Birmontienè T., Jarašiūnas E., Kūris E., Maksimaitis M., Mesonis G., Normantas A., Pumputis A., Vaitiekienė E., Vidrinskaitė S., Žilys J. (eds.) Lietuvos konstitucinė teisẻ (Constitutional law of Lithuania) Lietuvos teisès universitetas, Vilnius, pp. 103-131.

Jarašiūnas E. (2004) Lietuvos Respublikos Konstitucija ir Europos integracija (The Constitution of the Republic of Lithuania and European integration). In: Konstitucija, nacionaliné teise ir Europos teisè (The Constitution, national law and European law). Lietuvos Respublikos Konstitucinis Teismas, Vilnius, pp. 6-21.

Jarukaitis I. (2006a) Lithuania. In: Kellermann A.E., Czuczai J., Blockmans S., Albi A., Douma W. (eds.) The Impact of EU Accession on the Legal Orders of New Member States and (Pre-) Candidate Countries. Hopes and Fears. T.M.C. Asser Press, The Hague, pp. 385-407.

Jarukaitis I. (2006b) Adoption of the Third Constitutional Act and its Impact on the National Constitutional System. Teise / Mokslo darbai 60: 22-37.

Jarukaitis I. (2010a) Lithuania's Membership in the European Union and Application of EU law at National Level. In: Lazowski A. (ed.) The Application of EU Law in the New Member States: Brave New World. T.M.C. Asser Press, The Hague, pp. 209-241.

Jarukaitis I. (2010b) Report on Estonia, Latvia and Lithuania. In: Martinico G., Pollicino O. (eds.) National Judges and Supranational Laws: on the Effective Application of the EC Law and the ECHR. Europa Law Publishing, Groningen, pp. 167-204.

Jarukaitis I. (2011) Europos Sajunga ir Lietuvos Respublika: konstituciniai narystès pagrindai (The European Union and the Republic of Lithuania: The constitutional basis of membership). Justitia, Vilnius.

Jarukaitis I. (2014) Respect for the National Identities of the Member States as the General Principle of European Union Law. In: Švedas G., Nekrošius V., Machovenko J. (eds.) Lithuanian Legal System Under the Influence of European Union Law. Vilnius University, Faculty of Law, Vilnius, pp. 576-620.

Jarukaitis I., Civilka M., Lamanauskas T., Makauskaitė A. (2005) Elektroninių ryšių teisė (Electronic communications law). Eugrimas, Vilnius.

Jurka R., Ažubalytė R., Gušauskienė M., Panomariovas A. (2009) Baudžiamojo proceso principai. (Principles of criminal procedure). Eugrimas, Vilnius.

Kūris E. (2001) Lietuvos Respublikos Konstitucijos principai (Principles of the Constitution of the Republic of Lithuania). In: Birmontienè T., Jarašiūnas E., Kūris E., Maksimaitis M., Mesonis G., Normantas A., Pumputis A., Vaitiekienė E., Vidrinskaitė S., Žilys J. (eds.) Lietuvos konstitucinè teisè (Constitutional law of Lithuania). Lietuvos teisès universitetas, Vilnius, pp. 201-272.

Kūris E. (2004a) Lietuvos Respublikos Konstitucija ir Europos teisės iššūkiai (The Constitution of the Republic of Lithuania and the challenges of European law). Justitia 6: 34-46.

Kūris E. (2004b) Ekstranacionaliniai veiksniai Lietuvos Respublikos Konstituciniam Teismui aiškinant Konstituciją (Extranational factors affecting the interpretation of the Constitution by the Constitutional Court of the Republic of Lithuania). Teise / Mokslo darbai 50: 50-93.

Namavičius Z. (2004) Suverenitetas ir Europos Sajunga (Sovereignty and the European Union). In: Konstitucinių teismų vaidmuo Europos Sajungos kontekste (The Role of constitutional courts in the context of the European Union). Lietuvos Respublikos Konstitucinis Teismas, Vilnius, pp. 8-22.

Poiares Maduro M. (2003) Europe and the Constitution: What if this is as good as it gets? In: Weiler J.H.H., Wind M. (eds.) European Constitutionalism Beyond the State. Cambridge University Press, 2003, pp. 74-102.

Poiares Maduro M. (2004) How Constitutional Can the European Union be? The Tension between Intergovernmentalism and Constitutionalism in the European Union. Jean Monnet Working Paper 5/04: 1-53. 
Raz J. (1998) On the Authority and Interpretation of Constitutions: Some Preliminaries. In: Alexander L. (ed.) Constitutionalism. Cambridge University Press, Cambridge, pp. 152-193.

Römeris M. (1995) Valstybè ir jos konstitucinè teisè. II dalis. Konstitucinès institucijos. I tomas. Suverenitetas (The state and its constitutional law. Part II. Constitutional institutions. Vol. I. Sovereignty). Pradai, Vilnius.

Šileikis E. (2005) Alternatyvi konstitucinè teisè (Alternative constitutional law). Teisinès informacijos centras, Vilnius.

Štitilis D. (2006) Privataus gyvenimo elektroniniuose ryšiuose ribojimas nusikaltimų tyrimo tikslais (Restrictions of private life in electronic communications for the purpose of criminal investigations). Jurisprudencija 9(87): 69-75.

Švedas G. (ed.) (2004) Lietuvos Respublikos baudžiamojo kodekso komentaras. Bendroji dalis (198 straipsniai) (Commentary of Criminal Code of the Republic of Lithuania. General Part (Articles 1-98). Teisinès informacijos centras, Vilnius.

Švedas G. (2008) Kai kurios asmens perdavimo pagal Europos arešto orderị baudžiamajam persekiojimui teorinès ir praktinès problemos (Certain theoretical and practical issues of surrendering persons for criminal prosecution under the European Arrest Warrant). Teisé / Mokslo darbai 66(1): 8-18.

Švedas G. (2010) The influence of the European Union Law on the Contemporary Lithuanian Criminal Policy. In: Konarska-Wrzosek V., Lachovsky J., Wojcikiewicz J. (eds.) Wezlowe problemy prawakarnego, kryminologii i politykikarnej (Basic problems of criminal law, criminology and criminal policy), Wolters Kluwer Polska, Warsaw.

Švedas G., Merkevičius R. (2013) Presentation of national system of investigation, prosecution, evidence and procedural safeguards. Lithuania. In: Toward a Prosecutor for the European Union, vol. 1. Hart Publishing, Oxford, pp. 405-448.

Švedas G., Mickevičius D. (2009) Future of Mutual Recognition in Criminal Matters in the European Union: Lithuania. In: Vernimmen-Van Tiggelen G., Surano L., Weyembergh A. (eds.) The Future of Mutual Recognition in Criminal Matters in the European Union. Editions de l'Université de Bruxelles, Brussels.

Vadapalas V. (1998) Tarptautinė teisè (Public international law). Eugrimas, Vilnius.

Vadapalas V. (2002) Delimitation of Competences Between the European Union and the Member States: the Look from the Candidate Country. In: Melissas D., Pernice I. (eds.) Perspectives of the Nice Treaty and the IGC in 2004. Nomos, Baden-Baden, pp. 17-29.

Vadapalas V., Jarukaitis I. (2003) Constitution of the Republic of Lithuania, International Law and Accession to the European Union. In: Segado F.F. (ed.) The Spanish Constitution in the European Constitutional Context. Dykinson L.R., Madrid, pp. 473-488.

Vaičaitis V.A. (2006) The Republic of Lithuania. In: Kortmann C., Fleuren J., Voermans W. (eds.) Constitutional Law of 10 EU Member States: The 2004 Enlargement. Kluwer Law International, Oxford, pp. VI-1-64.

Vermeulen G., De Bondt W., Ryckman C. (2012) Rethinking International Cooperation in the Criminal Matters in the EU. Moving Beyond Actors, Bringing Logic Back, Footed in Reality. Apeldoorn, Antwerp.

Walker N. (2003) Late Sovereignty in the European Union. In: Walker N. (ed.) Sovereignty in Transition. Hart Publishing, Oxford, pp. 3-32.

Walker N. (2006) EU Constitutionalism in the State Constitutional Tradition. EU Working Papers. Law No 2006/21.

Werner W.G., De Wilde J.H. (2001) The Endurance of Sovereignty. European Journal of International Relations 7: 283-313.

Weyembergh A., Armada I., Brière C. (2014) European added value assessment - The EU Arrest Warrant: Critical Assessment of the Existing European Arrest Warrant Framework Decision. Research paper, Brussels. 
Žižienè S. (2014) Abipusio pripažinimo principo Europos Sajungos baudžiamojoje teisėje prielaidos, ịtvirtinimas ir veiksmingumas: Europos arešto orderis (Consolidation and effectiveness of the mutual recognition principle in European Union criminal law: The case of the European arrest warrant). In: Globalizacijos iššūkiai baudžiamajai justicijai (Globalisation Challenges for Criminal Justice). Registrų centras, Vilnius, pp. 443-456.

Open Access This chapter is licensed under the terms of the Creative Commons Attribution 4.0 International License (http://creativecommons.org/licenses/by/4.0/), which permits use, sharing, adaptation, distribution and reproduction in any medium or format, as long as you give appropriate credit to the original author(s) and the source, provide a link to the Creative Commons license and indicate if changes were made.

The images or other third party material in this chapter are included in the chapter's Creative Commons license, unless indicated otherwise in a credit line to the material. If material is not included in the chapter's Creative Commons license and your intended use is not permitted by statutory regulation or exceeds the permitted use, you will need to obtain permission directly from the copyright holder.

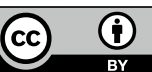

